\title{
Harnessing Wicked Problems in Multi-stakeholder Partnerships
}

\author{
Domenico Dentoni ${ }^{1} \cdot$ Verena Bitzer ${ }^{2,3}$ (D) $\cdot$ Greetje Schouten ${ }^{4}$
}

Received: 1 August 2016 / Accepted: 25 March 2018 / Published online: 7 April 2018

(c) The Author(s) 2018

\begin{abstract}
Despite the burgeoning literature on the governance and impact of cross-sector partnerships in the past two decades, the debate on how and when these collaborative arrangements address globally relevant problems and contribute to systemic change remains open. Building upon the notion of wicked problems and the literature on governing such wicked problems, this paper defines harnessing problems in multi-stakeholder partnerships (MSPs) as the approach of taking into account the nature of the problem and of organizing governance processes accordingly. The paper develops an innovative analytical framework that conceptualizes MSPs in terms of three governance processes (deliberation, decision-making and enforce$m e n t$ ) harnessing three key dimensions of wicked problems (knowledge uncertainty, value conflict and dynamic complexity). The Roundtable on Sustainable Palm Oil provides an illustrative case study on how this analytical framework describes and explains organizational change in partnerships from a problem-based perspective. The framework can be used to better understand and predict the complex relationships between MSP governance processes, systemic change and societal problems, but also as a guiding tool in (re-)organizing governance processes to continuously re-assess the problems over time and address them accordingly.
\end{abstract}

Keywords Wicked problems · Multi-stakeholder partnerships · Cross-sector partnerships · Governance processes · Systemic change $\cdot$ Roundtable on Sustainable Palm Oil (RSPO)

\section{Introduction}

How can multi-stakeholder partnerships (MSPs) contribute to addressing globally relevant and complex problems, such as global hunger, deforestation and biodiversity loss, climate change, poverty and violation of human rights? This

Verena Bitzer

v.bitzer@gmail.com

Domenico Dentoni

Domenico.dentoni@wur.nl

Greetje Schouten

schouten@rsm.nl

1 Management Studies Group, Wageningen University, Wageningen, The Netherlands

2 KIT Royal Tropical Institute, Amsterdam, The Netherlands

3 International Centre for Integrated Assessment and Sustainable Development (ICIS), Maastricht University, Maastricht, The Netherlands

4 Partnerships Resource Centre, Rotterdam School of Management, Erasmus University, Rotterdam, The Netherlands question generates fierce debate among academics, policy makers and managers, based on the common observation that MSPs, as a specific organizational form that combines public and private actors across sectors (Selsky and Parker 2005), have risen in influence on global governance over the last two decades. MSPs are broadly defined as a collaborative form of governance involving mainly business actors and civil society organizations that come together to find a common approach to a complex problem that affects them all (Roloff 2008; Rasche 2012). Examples of MSPs seeking to tackle these problems abound, including the Forest Stewardship Council, Marine Stewardship Council, Roundtable on Sustainable Palm Oil, Roundtable on Responsible Soy, Alliance for Water Stewardship, or the Sustainability Consortium, suggesting that they have become elements in innovative solutions for deep-level changes in environmental, social or economic systems (van Tulder et al. 2016). However, despite their attempts of complementing public institutions in domains where governments are not able or willing to regulate (Scherer and Palazzo 2007), the problems that MSPs seek to address remain far from being tamed or, 
in some cases, have become even more acute (e.g., Levin et al. 2012).

An increasingly widespread perspective suggests that partnerships can address these complex societal problems by triggering or contributing to systemic change (Waddell et al. 2015; Waddock et al. 2015). Overall, recent studies emphasize two relevant dimensions of systemic change in relation to partnerships (Geels and Schot 2007; Senge et al. 2007; Loorbach 2010). First, systemic change involves interconnected change across multiple spheres (e.g., natural, cultural, institutional, technological, organizational, individual) and subsectors (e.g., change in the food and agricultural subsector may require and bring about changes in other subsectors such as finance, energy, health or education). This has been referred to as breadth of change (Waddell et al. 2015). Second, systemic change entails a power shift among actors in society and a related redistribution of resources in a system. This relates to the depth of change (Waddell et al. 2015). From this angle, the persisting challenge is whether partnerships trigger or support breadth and depth of change to an extent that adequately addresses complex societal problems (Waddock et al. 2015). This relationship between reaching breadth/depth of systemic change and addressing societal problems is particularly challenging to understand-let alone to empirically measure-since complex systems and problems are inherently nonlinear (Waddock et al. 2015).

A recent strand of the literature argues that forms of collaborative governance, encompassing processes of interaction, deliberation, decision-making and enforcement (e.g., of codes of conduct, standards and best practices), may not be suitable to the nature of the problems that they seek to address (e.g., Hospes et al. 2012; Waddock 2013)—nor to trigger or support systemic change to a sufficient breadth or depth (Waddock et al. 2015). Problems like fisheries depletion or tropical deforestation are highly complex, entail many interactions and interdependencies, and are characterized by conflicting views amidst considerable knowledge uncertainty - all of which pose formidable organizational challenges (Ferraro et al. 2015, p. 2). This raises the question whether MSPs, as a form of collaborative governance, can help tackling complex problems, or at least avoid to make them worse (Bitzer and Glasbergen 2015), without a deeper understanding of the nature of the problems that they seek to address (e.g., George 2014). As Ferraro et al. (2015) recently highlighted, understanding how organizations can contribute to addressing complex problems requires further research on the connections between organizational action and field-level changes. From a governance perspective, the nature of these problems requires "the pursuit of bold ideas and the adoption of less conventional approaches" (Colquitt and George 2011, p. 432). An open question is how MSPs can pursue and adopt these ideas and approaches.
To contribute to the debate on how partnerships (can) address complex problems - and thus trigger or support broader and deeper processes of systemic change-this paper proposes an analytical framework that assesses whether and how MSPs harness the nature of the problems around which they are set up. In the context of MSPs, we define harnessing a problem as the approach of (1) taking into account its nature and (2) organizing the partnership governance processes accordingly. First of all, to consider the nature of problems, we apply the original definition of wicked problems (Rittel and Webber 1973) in the context of MSPs since the aforementioned societal problems are wicked in nature (Batie 2008; Dentoni et al. 2012). Wicked problems are realms of ill-defined issues that, relative to "tame" problems (Conklin 2006), cannot be framed and understood in linear cause-symptom-effect relationships (knowledge uncertainty), evolve unpredictably over time (dynamic complexity) and involve conflicts of values among stakeholders (value conflict). As such, wicked problems require fundamentally different approaches than tame problems-governance approaches which can instigate deeper and broader systemic change (Ferraro et al. 2015).

To assess whether and how MSPs harness the problems that they are addressing, we investigate the different governance processes, including formal and informal elements (Rufin and Rivera-Santos 2012) that support MSPs and their participants to take into account and respond to the nature of the problems at hand. Harnessing wicked problems would imply having governance processes in MSPs which continuously re-assess and re-address problems over time and seek an acceptable temporary synthesis between conflicting stakeholders' views and values (Termeer et al. 2015). Specifically, to understand whether and how MSPs harness wicked problems, we focus on three interrelated governance processes that are critical for keeping awareness and acting on the problems at hand: deliberation, decision-making and enforcement (Schouten and Glasbergen 2012). This study is meant to deepen analytical knowledge on what harnessing is and how it takes place in the context of MSPs through a framework which guides empirical operationalization. While the paper does not aim to normatively prescribe how MSPs should harness problems and how they would be most effective at this, we do distill a number of practical recommendations for MSP practitioners based on both the framework and the findings from the illustrative case study introduced below.

The proposed analytical framework is applied to the case of the Roundtable on Sustainable Palm Oil (RSPO), which serves as an empirical illustration of whether and how an MSP harnesses wicked problems. With more than 10 years of history, governance issues in the RSPO have been widely studied in academia and critically assessed by external stakeholders over time. Throughout these years, the RSPO has 
been dealing with several entangled issues afflicting palm oil production systems, local natural and socioeconomic systems as well as the global ecosystem (see Harnessing Wicked Problems in the RSPO: historical background and Harnessing Wicked Problems in the RSPO: an empirical illustration Sections). As such, the RSPO illustrates the interrelatedness among governance processes in MSPs, the problems to address and the processes of systemic change that partnerships wish to trigger or support (Waddock et al. 2015).

\section{Methods}

This paper seeks to make a conceptual contribution, as it advances an analytical framework to describe and understand whether and how MSPs harness wicked societal problems from a governance perspective. The framework builds upon two underpinnings: the notion of wicked problems and theories of governance that focus on the nature of problems at hand. Accordingly, the following three steps of literature review support the development of the analytical framework:

- A review of the notion of wicked problems, its relationship with systemic change and our proposed operationalization in the context of MSPs (The Nature of Wicked Problems Section);

- A discussion of the literature on the governance of wicked problems, first in the public policy domain and then in the context of MSPs as forms of private governance (Governing Wicked Problems Through MSPs Section);

- An in-depth view into three key governance processes of MSPs, namely deliberation, decision-making and enforcement (Understanding the Governance Processes of MSPs Section).

These steps of conceptual development support the proposed framework, which involves the definition and operationalization of whether and how MSPs harness wicked problems (Harnessing Wicked Problems in MSPs: An analytical framework Section). This operationalization takes place through a $3 \times 3$ matrix (Table 2) since the three interrelated MSP governance processes (deliberation, decision-making and enforcement) are analyzed along the three identified dimensions of wicked problems (knowledge uncertainty, value conflict and dynamic complexity). Within this $3 \times 3$ matrix, each of the nine generated cells advances a set of questions and related qualitative indicators reflecting whether and how MSPs harness the three key dimensions of wicked problems in the three governance processes. We derive these key indicators from a synthesis of the reviewed literature and our definition of harnessing problems.
As mentioned, we use the Roundtable on Sustainable Palm Oil (RSPO) as an empirical illustration to showcase how the analytical framework can guide the operationalization of whether and how MSPs harness wicked problems (Harnessing Wicked Problems in the RSPO: historical background and Harnessing Wicked Problems in the RSPO: an empirical illustration Sections). The RSPO provides a fertile empirical ground to assess and iteratively enrich our proposed analytical framework, as it is one of the most established MSPs (founded in 2004) and has attracted significant attention by scholars over recent years. As a result, there is a richness of academic studies (i.e., peer reviewed publications) as well as secondary sources (e.g., reports, websites, blogs, newsletters, etc.) on the RSPO, which offer sufficient insights for the purpose of this paper without requiring new empirical research. Taking the RSPO as an illustrative case study serves two purposes: firstly, to clarify the analytical argument developed in this paper by giving a concrete example of its application, and secondly, to demonstrate the empirical relevance of the approach developed in the paper (Eckstein 1975). Since the framework has an analytical nature rather than a prescriptive one, it is beyond the scope of this empirical illustration to evaluate the effectiveness of the RSPO in harnessing the wicked problems or to instigate sufficient depth or breadth systemic change during its history. The inherently nonlinear nature of wicked problems and of the systems in which these are situated (Waddock et al. 2015) would make it empirically impossible to demonstrate causal relationships between governance approaches in the RSPO, the nature of systemic change and problem mitigation. Instead, the RSPO case shows that analyzing how MSPs harness wicked problems in governance processes helps explaining the MSPs' organizational evolution over time (Discussion and conclusion Section).

To provide a rich illustration of the RSPO case, we first reviewed the literature on the RSPO since its origins in 2004 , for a total of 45 journal articles. Second, with a first draft of the $3 \times 3$ matrix of our analytical framework at hand, we coded information from 36 of these articles according to how the RSPO has harnessed the wicked problem at stake during the three identified governance processes (while the remaining 9 out of 45 articles did not provide relevant information, e.g., they focused only on technical aspects of palm oil production and related standards rather than on governance processes). Third, we used the codes from the 36 articles to assess whether they reflected the three governance processes and three wicked problem dimensions of the $3 \times 3$ matrix. By comparing the analytical framework against these empirical codes, we found that the $3 \times 3$ matrix was a helpful tool to understand how an MSP harnesses the key dimensions of wicked problems. Finally, we developed tables (Tables 3, 4, 5) 
that empirically illustrates our analytical framework based on a synthesis of the empirical codes from the journal articles and secondary sources from multiple stakeholders (Harnessing Wicked Problems in the RSPO: an empirical illustration Section).

\section{Literature Review}

\section{The Nature of Wicked Problems}

To understand how MSPs deal with the nature of problems, we first revisited the concept of wicked problems. Rittel and Webber (1973) coined the term "wicked" to describe highly intractable problems facing the planning of the growing city of San Francisco in the early 1970s. Wicked problems differ from "tame" problems because they are characterized by ambiguous and uncertain settings and elicit strongly conflicting views held by stakeholders when it comes to identifying the cause of and solution to a problem. As a result, wicked problems are difficult, if not impossible, to define and solve. While the literature on policy and public administration has widely adopted the definition introduced by Rittel and Webber in ten points, studies have focused in particular on the intractable and dynamic nature of wicked problems (Batie 2008), the social construction of problem definitions and perceptions (Roberts 2000; Weber and Khademian 2008), and the futility of attempts to solve wicked problems (Conklin 2006; Jentoft and Chuenpagdee 2009). Recent theorizing on wicked problems has also identified additional features of "super wicked" problems, such as climate change, including: "time is running out," "those seeking to end the problem are also causing it," there is "no central authority" able to address the problem, and policies are limited to presentday considerations and "discount the future irrationally" (Lazarus 2008; Levin et al. 2012).

In relation to its original definition (Rittel and Webber 1973), we seek to operationalize the concept in a way that is more relevant and easier to use in the context of the governance processes of MSPs. In particular, we propose three key features (or dimensions) that distinguish wicked problems: (1) knowledge uncertainty, (2) value conflict among multiple stakeholders and (3) dynamic complexity, in that they have no unique and final solution(s) or outcome(s) (Kreuter et al. 2004; Batie 2008). In Table 1 we present the ten characteristics of wicked problems as described by Rittel and Webber (1973) and the three dimensions identified accordingly. Knowledge uncertainty refers to both the formulation of the problem(s) and the potential solutions such that stakeholders have to make decisions in an incomplete information setting. Uncertainty derives from limited availability of information due to gaps in scientific knowledge of the problem(s) and solution(s) and is aggravated by cognitive limits of decision-makers to adequately deal with, process and put into use the information that is available (Dietz et al. 2003; Hajer 2003; Batie 2008; Head and Alford 2013). The presence of value conflict represents another dimension of wicked problems. Multiple stakeholders are affected by wicked problems, each with their own set of values, frames, perceptions and interests, which may not only diverge but downright oppose and clash with one another. The wickedness of problems is such that there may not even be a general consensus on broad societal goals and much less a consensus on what type of information and knowledge would be relevant to address a particular wicked problem (Batie 2008). Hence, trade-offs between values are likely to occur (Weber and Khademian 2008). Finally, as wicked problems involve complex interdependencies, they are volatile and evolve over time, sometimes linearly but frequently unpredictably and unexpectedly (Jentoft and Chuenpagdee 2009). This dynamic complexity implies that there are no "solutions" in the sense of definite and objective answers to the problem over time (Rittel and Webber 1973). This characterization of wicked problems suggests that addressing them requires deep and broad changes in the complex systems which they are situated (Ferraro et al. 2015; Waddock et al. 2015).

\section{Governing Wicked Problems Through MSPs}

The key implication of these dimensions of wicked problems is that no stakeholder can effectively respond to wicked problems independently from other stakeholdersindividual action against wicked problems has limited or no effectiveness if uncoordinated from the action of others (Conklin 2006). Traditional approaches based on public governance are deemed unsuitable in this context (Colquitt and George 2011). Alternative approaches are needed, including alternative ways of observing the wickedness of problems and enabling the conditions of the governance system in which actors operate to deal with the problems (Termeer et al. 2015). Scholars have therefore emphasized the importance of developing a network and systems perspective for approaching wicked problems (Weber and Khademian 2008). Others have paid attention to the value conflicts between stakeholders and have proposed collaborative and deliberative forms of governance as a strategy for inclusion, reflection and responsiveness to multiple perspectives (e.g., Sachs et al. 2010). Termeer et al. (2015) reiterated the need for a dynamic perspective on wicked problems to ensure continuous assessments of the problem over time. They argued for "reflexivity" in problem frames, "resilience" and "responsiveness" to adapt flexibly to changing circumstances or changing public demands, and "revitalization" to break with established patterns of behavior in deadlock situations. Even then, reaching acceptable and stable outcomes is far 


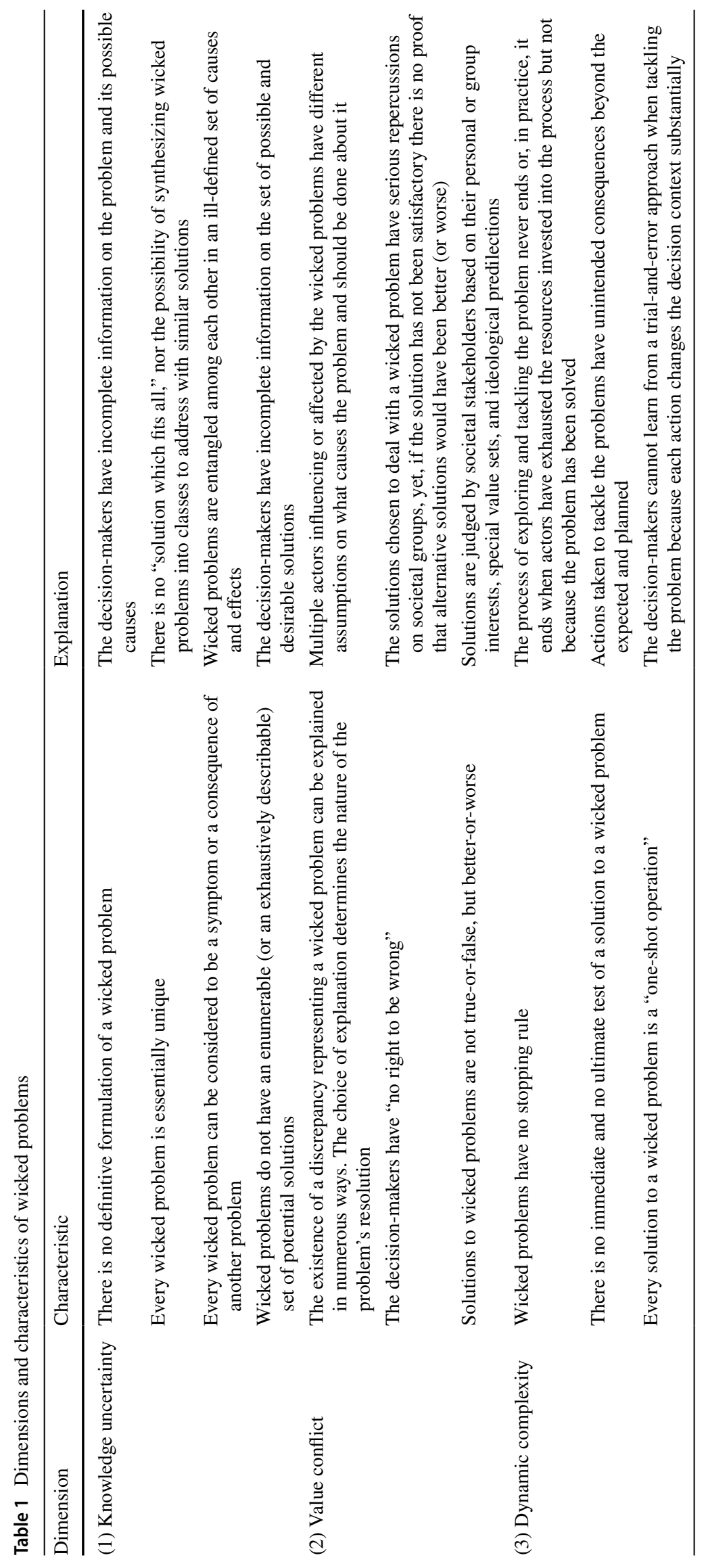


from being guaranteed given the messiness of the problems (Ney and Verweij 2014).

"Harnessing wickedness," i.e., the approach of taking into account and responding to the different dimensions of wicked problems, thus requires a governance process that enables networked action, stimulate collective processes and deal with complex dynamics to achieve small wins (Termeer et al. 2015). Previous studies have indicated the potential of MSPs as collaborative arrangements in which different actors, e.g., from business, non-governmental organizations (NGOs) and, in some cases governments and academia, join forces to find a collective approach to a problem that affects them all (e.g., Roloff 2008; Dentoni et al. 2012). MSPs are often conceptualized as forms of private governance (e.g., Gulbrandsen 2004; Pattberg 2006; Mena and Palazzo 2012). This concept refers to "a form of socio-political steering in which private actors are directly involved in regulating - in the form of standards or more general normative guidancethe behavior of a distinct group of stakeholders" (Pattberg 2006, p. 591). As such, MSPs may be able to exploit the interdependencies between actors necessary to address wicked problems for three main reasons (Dentoni and Bitzer 2015). First, knowledge uncertainty, including unknown, unclear or hidden cause-effect relationships underlying the problem at hand, is dealt with by involving actors who cut across different knowledge domains. Second, value conflicts between stakeholders and struggles over the nature of the problem can be brought to the table and discussed through deliberation and negotiation to find a temporarily acceptable synthesis. These interaction processes are one of the major sources of sense making and problem (re-)framing (Rivera-Santos and Rufin 2011). Finally, dynamic complexity, expressing that wicked problems mutate over time, demands a continuous process of knowledge production to adapt to changing problem contexts (Crona and Parker 2012). As they often operate through networked structures and flexibility in decision-making and action, MSPs could constitute promising and "less conventional approaches" (Colquitt and George 2011, p. 432) to deal with the nature of wicked problems.

\section{Understanding the Governance Processes of MSPs}

Despite growing elaborations on wicked problems and increased recognition of the type of governance needed to address these issues, Ison et al. (2015) noted that there is limited evidence that understandings about "wicked problems" have been incorporated into governance processes, such as those by MSPs. This refers to the question of whether or not, and to what extent, understandings about the wickedness of problems are incorporated into the structures and enacted through practices that determine how partners in an MSP interact with each other, and how they make, implement and monitor agreements.

MSPs emerge when a particular problem becomes urgent for specific stakeholders who believe that they need to do something about it, but could not approach it on their own (Roloff 2008). Collaboration typically starts among a small number of organizations, usually involving NGOs and a group of businesses who self-select to be pioneer members, either to gain reputational benefits vis-à-vis competitors or to establish a level playing field (Zeyen et al. 2016). While little is known on why certain groups of stakeholders are involved in the formation of an MSP and others are not (Fransen and Kolk 2007), self-selection tends to be based on the belief that together these actors are the "right ones" to address the problem at hand (Schouten and Glasbergen 2011). Afterward, this pioneering group will negotiate the terms of engagement and the conditions that determine further MSP membership (Zeyen et al. 2016). On the one hand, MSPs are keen to claim legitimacy based on the participation of "all categories of stakeholders" (Cheyns and Riisgaard 2014). On the other hand, defining membership becomes political when the founding members prefer certain stakeholders over others, since this is an opportunity to shape the range of voices and interests represented within MSPs (Fransen and Kolk 2007). Formal barriers to joining MSPs may be low, but de facto membership opportunities are often tied to the availability of resources and capabilities, including the ability to conform to already established formats of participation, which may limit the inclusiveness of MSPs (Cheyns 2014). Other organizations purposefully choose not to join and participate as outsiders in different ways, e.g., by monitoring and campaigning (Pesqueira and Glasbergen 2013).

After its initial formation, governance by MSPs manifests in a set of three processes that continuously evolve and interplay over the life of the partnership (Gray 1989; Schouten and Glasbergen 2012). The first governance process describes the interaction, negotiation and discussionhere captured as deliberation-between the actors involved. Since MSP members come from different sectoral, cultural and ideological backgrounds, divergent and possibly conflicting objectives and motivations are likely to be present. In this sense, MSPs are recognized as sites of negotiation about norms and interpretations rather than mere forums for the planning and implementation of pre-identified policy objectives (Forsyth 2010). Processes of deliberation are often conceptualized against the normative ideals of deliberative democracy, describing processes dominated by open and fair exchange of arguments to understand each other's perspectives, in which power relations between participants are neutralized (Dryzek and Stevenson 2011). Deliberative processes are also thought helpful to grasp the complexity of the issue and connect individual interests to broader 
societal interests, paving the way for reaching mutual agreement (Baur and Arenas 2014). In recognition of preexisting inequalities and power imbalances between actors, which could distort the deliberative processes, formalized endeavors to ensure representative inclusion of different stakeholder categories can be observed in some MSPs (e.g., Fortin 2013; Klooster 2010; Mena and Palazzo 2012). Other MSPs have established working groups for fact finding as a way to address power asymmetries and contentious issues (Schouten and Glasbergen 2011). Nonetheless, many studies reveal that even such affirmative formal arrangements are unlikely to compensate for the dominance of particular participants, power plays and coalitions within MSPs (Schouten et al. 2012; Fortin 2013; Cheyns and Riisgaard 2014).

The second governance process of MSPs concerns decision-making. Ideally, the process of deliberation leads to a shared problem definition, which enables the identification and selection of different approaches for implementation. As MSPs are expected to build their decision-making processes in a way that power differences between the various actors involved are offset, many MSPs have adopted a "chamber" governance structure, in which stakeholders are grouped in different categories and each has one vote (Mena and Palazzo 2012). Others have a governing board where different groups of stakeholders are represented equally to achieve voting balance, or even regular rotation of positions among stakeholder groups in decision-making bodies (Fransen and Kolk 2007). However, this refers only to formal decisionmaking procedures and structures, whereas negotiation and bargaining is likely to occur a priori through informal practices. This is not only due to differences in problem framing, but crucially because the decision about which approach to select is closely connected to the question of who will contribute what in the implementation process (Roloff 2008). Different studies have shed light on the negotiation practices preceding formal decision-making, in which already pre-existing relations and power imbalances between actors seem to be re-inscribed rather than neutralized (Schouten et al. 2012; Fortin 2013). Such perspectives have highlighted in particular the weak representation of powerless and "vulnerable" groups, such as small-scale producers, in these processes (Cheyns and Riisgaard 2014). The result is that MSPs' approach for implementation is often not the "scientifically best, environmentally strongest, or socially the most ideal," but one that achieved some level of agreement and is likely to be easy to implement (Klooster 2010). Roloff (2008) argued that compromise and appeasement orientation is necessary to keep organizations involved despite mutual wide-ranging differences and avoid the exodus of those organizations that feel disadvantaged by decision-making.

The third process concerns the enforcement of decisions and agreements, i.e., implementation and monitoring, which are critical for MSPs' claims on effectiveness. Many
MSPs work through sustainability standards as a form of voluntary private regulation, where standard compliance is verified through regular third-party monitoring to achieve objective, independent measurements (O'Rourke 2006; Hatanaka and Busch 2008). MSP members are expected to be the first adopters of the jointly developed standards, but MSPs also aim to generate widespread standard diffusion beyond direct members. This requires creating incentives for standard adopters, including material benefits, such as price premiums and selective supply chains, and social legitimation (Wijen 2014). However, third-party monitoring of standards is expensive, involving costs of certification and costs of compliance. This has been shown to create monitoring fatigue and raises the risk of symbolic adoption to reap the standards' benefits without bearing the associated costs (Mena and Palazzo 2012; Wijen 2014). Moreover, studies have revealed how standards and certification, instead of being neutral tools to implement MSPs' decisions, have also given rise to political contestation between the actors involved on issues of equity, effectiveness and inclusiveness (Schouten and Glasbergen 2011; Bitzer and Glasbergen 2015). Thus, enforcement is not simply a transmission of policies and practices from the global to the local level, but is entangled in the continuous negotiation over rights and responsibilities and struggles over the nature of the problem and its appropriate solutions (Andonova et al. 2009).

Such contestation can lead MSPs to re-open discussions about problem definition and approaches, thus starting again with amending the deliberation process in the course of time. Iterations can also occur as the group of actors in MSPs is likely to change over time, since some actors may leave the partnerships and others join, which adds new views on the issue at stake. Thus, MSPs tend to interplay between deliberation, decision-making and enforcement processes in their life cycle, during which membership composition also changes (Roloff 2008).

\section{Harnessing Wicked Problems in MSPs: An Analytical Framework}

Thus far, our review of the literature has pursued the following line of argumentation: (1) wicked problems can be distinguished according to three key dimensions; (2) scholars have recently advocated for collaborative forms of governance, such as MSPs, to address the wicked nature of problems; and (3) governance in MSPs is characterized by three main processes that interplay over time after a formation phase. These three governance processes are characterized by continuous negotiation between the actors involved, where voice and power remain key ingredients (Bäckstrand 2006). Yet, studies also reveal the fluidity of MSP governance as a continuous process of re-understanding, 
re-assessing, adjustment and adaptation (e.g., Klooster 2010; Schouten et al. 2012). This also suggests to take an analytical view on partnerships, which leads to a more specific definition of harnessing wicked problems in MSPs. In particular, this is defined as the approach of understanding and acting upon the dimensions of the addressed problems (knowledge uncertainty, value conflict and dynamic complexity) during the different governance processes of MSPs (deliberation, decision-making and enforcement).

In line with the iterative character of the different governance processes in MSPs, we understand harnessing wicked problems in MSP governance as inherently iterative. Taken together, the three interrelated processes of deliberation, decision-making and enforcement reflect an interconnected, nonlinear process over time in which the key dimensions of wicked problems can potentially be harnessed:

1. Harnessing knowledge uncertainty collectively gathering, interpreting and using data on the causes, symptoms and consequences of the problem that the partnership aims to tackle.

2. Harnessing value conflict collectively gathering, interpreting and synthesizing the variety of values represented by the stakeholders influencing or affected by the problem at hand, in particular those that are not permanent MSP members.

3. Harnessing dynamic complexity collectively gathering knowledge from stakeholders and making sense of how the problem is evolving over time.

To guide the analysis of whether and how MSPs harness wicked problems, Table 2 presents a $3 \times 3$ matrix showing the three key dimensions of wicked problems combined with three main governance processes of MSPs. Based on the literature review presented in Literature Review Section, the table contains two main elements to operationalize the concept of harnessing wicked problems in MSP governance. First, the matrix presents one key research question for each of the nine quadrants of the matrix to facilitate an in-depth inquiry which connects governance by MSPs with the nature of wicked problems. Second, the matrix identifies qualitative indicators that empirically reflect the approach of harnessing wicked problems, i.e., organizing governance processes in MSPs according to the nature of wicked problems. These indicators do not represent prescriptive recommendations, but should be understood as a proposed operationalization of what harnessing wicked problems is. First, the qualitative indicators involve the participation of stakeholders from a diversity of backgrounds, knowledge perspectives and conflicting values in line with the notion that organizations adapting to the nature of problems are multi-vocal (Dentoni and Ross 2013; Ferraro et al. 2015; Ison et al. 2015). Thus, the focus of harnessing problems goes beyond stakeholder selection-which implies granting access but not necessarily providing the conditions for stakeholders to participate and continuously reframe the problems. Furthermore, harnessing plays out through a combination of formal and informal elements, understanding that both enact the identified governance processes in MSPs. For instance, formal elements, such as the allocation of resources to motivate the participation of resource-poor stakeholders, are met with informal elements such as practices of knowledge sharing, debating, arguing and acting. This combination of formal and informal elements may not only determine which stakeholders participate and to what extent, but more generally how MSPs harness wicked problems (e.g., how MSPs make sense of constantly changing problems or how they jointly reflect on new knowledge and information) (Waddell et al. 2013; Hamilton 2013; Cheyns and Riisgaard 2014).

\section{Harnessing Wicked Problems in the RSPO: Historical Background}

The global palm oil controversy has been characterized by conflicting frames about palm oil production, whereby some hail palm oil as a wonder crop-as it generates the highest production of vegetable oil per hectare of land and is of major importance for economies in Southern producing countries-while others, such as international NGOs, frame palm oil production as an important cause of deforestation, loss of biodiversity, forest fires, air pollution, greenhouse gas emissions, land conflicts and/or social-political tensions within communities (Hospes et al. 2017). ${ }^{1}$ The proposed analytical framework, in connection with the suggested key research questions and indicators, allows interpreting the case of RSPO in light of whether and how it has been harnessing the wicked problem in its history.

\section{Phase 1 (2002-2005): Partnership Establishment and the Denial of the Wicked Problem}

In the early 2000s, the rapidly increasing global demand for palm oil and the resultant expansion of areas planted to oil palm, especially in Southeast Asia, led to large-scale public outcry and debate on the sustainability of palm oil production, especially in Europe. Media and environmental NGO campaigns started fierce attacks against the palm oil industry, including large multinational consumer companies. In response to the heightened public pressure, in 2002 WWF (World Wildlife Fund) and Unilever started discussing the establishment of a Roundtable, based on the shared

\footnotetext{
${ }^{1}$ For an overview of sustainability issues associated with palm oil production see "Appendix".
} 


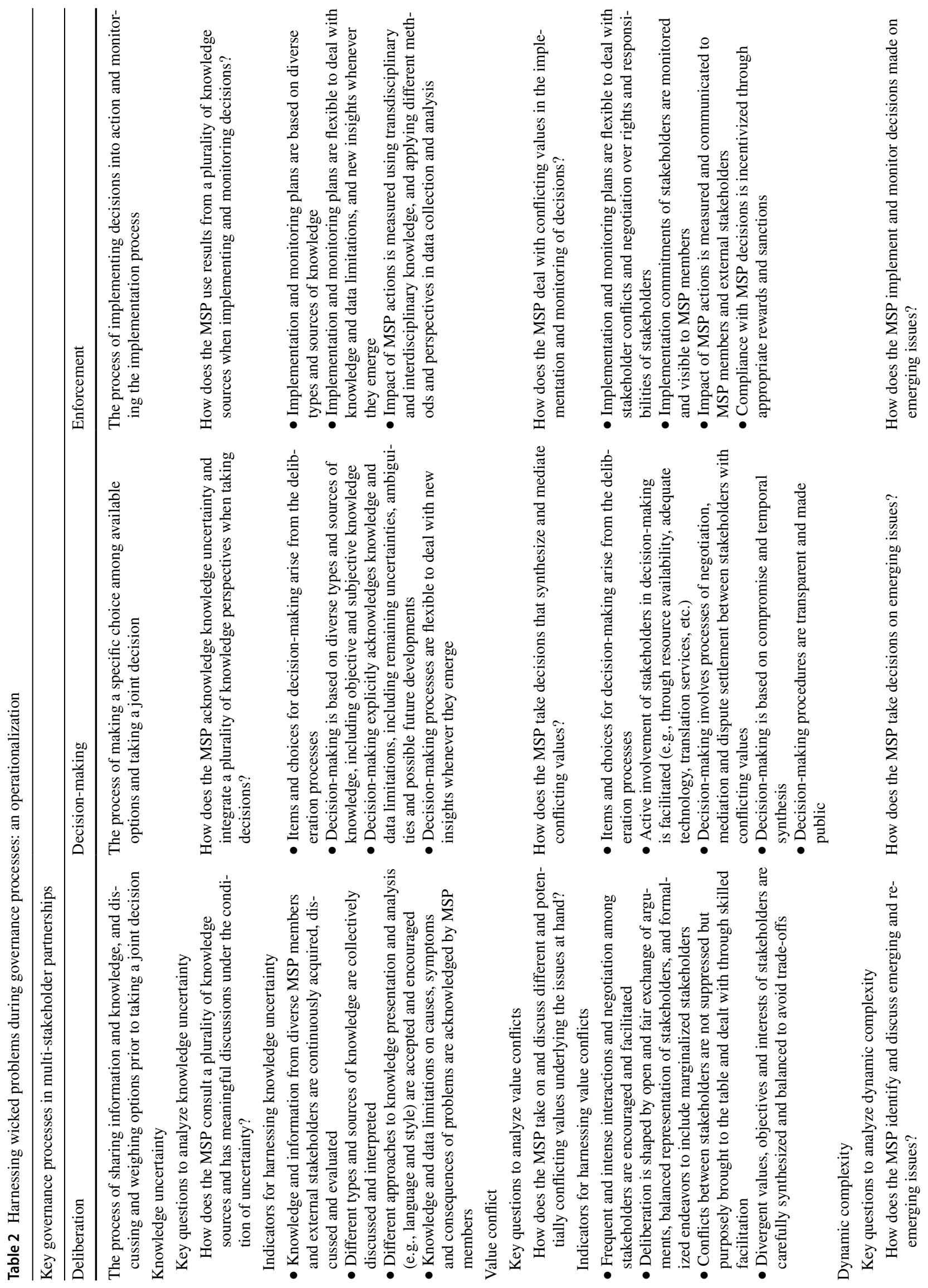




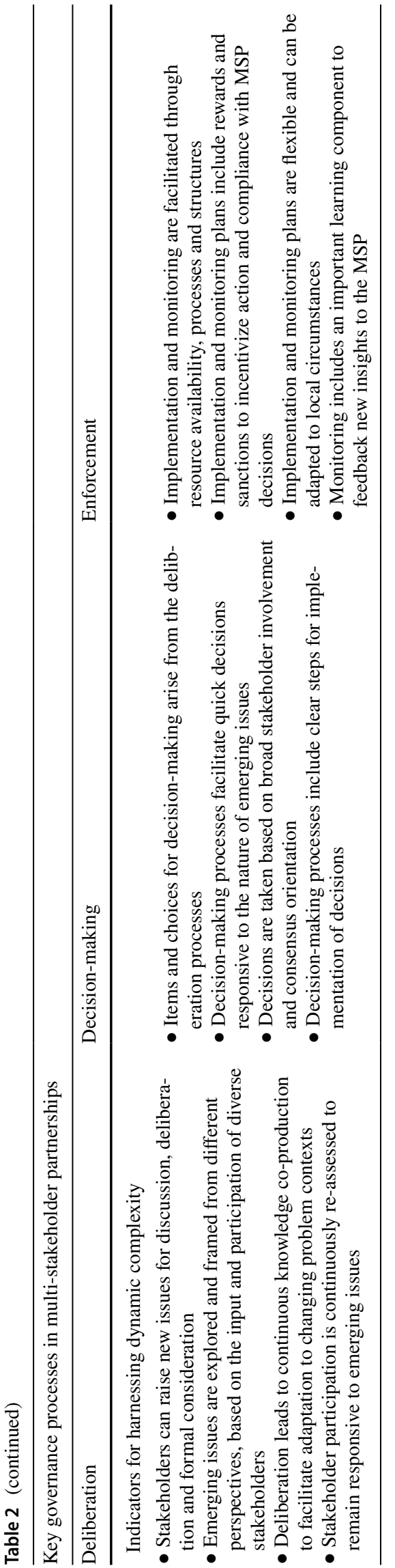

perception that palm oil production was associated with deforestation. WWF and Unilever decided to invite other stakeholders to join the discussions in an attempt to find answers that would satisfy all stakeholders in the commodity chain as well as environmental conservationists (Omont 2004). In 2004, the RSPO was formally established under Swiss law with an initial membership of 47 organizations from business and civil society.

However, the problem of palm oil production turned out not to be as straightforward as the organizations first assumed. The UK-based environmental consultancy firm ProForest was hired to conduct technical studies to develop further insights into the issue. These studies formed the basis for the initial discussions between stakeholders. Although there was still no consensus about the exact link between palm oil and deforestation, using the technical studies by ProForest helped to narrow down and clearly demarcate the problem at an early stage (Nikoloyuk et al. 2010). As only relatively few organizations were involved in the early days of the RSPO, Unilever and WWF were able to hold key positions during the multi-stakeholder processes and steer the discussions based on pragmatism and technical rationality (Ponte and Cheyns 2013). This ensured that value conflicts between stakeholders were reduced to a minimum and partially pushed outside the RSPO boundaries (Schouten and Glasbergen 2012).

Priority in the newly founded RSPO was given to establishing credible sustainability criteria that were acceptable to all stakeholders (Omont 2004). For this purpose, in 2004 the Criteria Working Group (CWG) was formed with the objective of presenting Principles and Criteria (P\&C) for sustainable palm oil by 2005 . The CWG was based on decision-making through consensus; no decision could be taken against the will of one of the main groups. The draft $\mathrm{P} \& \mathrm{C}$ were prepared by ProForest, based on their own studies and existing guidelines by companies. NGOs fed this process by supplying additional data on environmental issues and effective communication strategies, including in-depth field research, photographic and interview evidence of unsustainable practices, and direct lobbying of firms and governments, especially European governments, and RSPO member firms such as Unilever (Nesadurai 2013). However, the CWG process was criticized internally for insufficient representativeness - no smallholders were included and few representatives from Africa-and for not giving a clear and active role to researchers (Omont 2004). Soon after the first presentation of the draft $\mathrm{P} \& \mathrm{C}$ in 2005 , a smallholder taskforce was established which decided to create a system of group certification for smallholders, so that individual smallholders could share the costs of certification and be certified under a single certificate. The RSPO thus reacted swiftly to the emerging criticism that its main future instrument (the 
P\&C) would be applicable to large-scale plantations only, thereby implicitly excluding smallholder farmers.

Assessing this first phase in terms of systemic change, it becomes clear that the RSPO was limited in reaching breadth as well as depth of change. Although the RSPO was able to make connections between different spheres to a limited extent - by creating a deliberation space in which multiple stakeholder could interact-the RSPO did not trigger substantial changes in other subsectors. Moreover, although RSPO members were able to create a new deliberation space, this did not lead to a significant shift in power in the relationships among stakeholders in this phase.

\section{Phase 2 (2006-2009): First Glimpses into the Wickedness of Palm Oil Production}

The first generic P\&C were approved in 2007 , and the certification mechanism was adopted in 2008. However, the ratification of the $\mathrm{P} \& \mathrm{C}$ was preceded by a process of contestation. While at first, the problem definition was rather narrow, new problems related to palm oil continued to surface on the agenda. From various internal and external sources, criticism arose which targeted the content of the $\mathrm{P} \& \mathrm{C}$ and brought to light the complexity of palm oil. For instance, Oxfam, as a new member to the RSPO, published a report in 2006 to raise awareness of the relationship between palm oil and poverty, while previously the focus of the discussions in the RSPO was almost exclusively on the environmental dimension of palm oil production, and in particular its link with deforestation (Pesqueira and Glasbergen 2013). Oxfam even invited smallholder farmers to speak at an RSPO meeting, exposing human rights violations of companies. This triggered value conflicts with stakeholders from Malaysia and Indonesia who denied these allegations and insisted that palm oil did not contribute to poverty, but rather that palm oil production had brought significant economic growth to both countries, resulting in substantial poverty reduction. This conflict continued over the years, with both sides supplying more "evidence" in the form of reports supporting their perspective.

The discussions on this became so prominent that the RSPO saw itself forced to adjust both its P\&C and its governance structure. Firstly, as a result of Oxfam's advocacy, social criteria were better specified and linked to international practices, and the international norm of Free, Prior, and Informed Consent (FPIC) was integrated in the P\&C in 2007. FPIC is a key principle in international law with regard to ensuring the rights of indigenous people, and demands of investors or companies to engage with indigenous peoples and local communities prior to the establishment of new palm oil plantations and other agricultural development on customary land (Pesqueira and Glasbergen 2013). Such engagement is supposed to be based on non-coercive negotiations, participatory assessments, and benefit-sharing agreements in which local communities can grant or withhold consent to activities that affect their cultures and rights (op cit.). Second, in 2008, the RSPO also created a Dispute Settlement Facility, to be used as a mediation facility to help resolve disputes between local communities and palm oil producers in cases where at least one party is an RSPO member. An Advisory Group was established to help set up the Dispute Settlement Facility and to monitor any arising cases and give recommendations to the RSPO.

In 2009, Oxfam Novib demanded an official investigation of the National Interpretation process in Colombia which had been led by the palm oil industry from 2008 to 2009 . The process was characterized by strong power asymmetries among stakeholders and clashes between their different values, giving rise to strong contestation of RSPO legitimacy by local actors who resisted the expansion of oil palm cultivation (Marin-Burgos et al. 2015). The official evaluation concluded that the National Interpretation process neither included representatives of Afro-Colombia, indigenous people and peasant organizations nor utilized an appropriate methodology for effective stakeholder participation (MarinBurgos et al. 2015). Also the environmental dimension of palm oil production turned into a more complex issue than what was reflected during the early phase of the RSPO. In 2007, Greenpeace as an external actor (non-member) published a report ("Cooking the Climate") linking CO2 emissions from cleared peat lands in Indonesia to activities of RSPO members. The entry of this report into the arena of palm oil politics destabilized the attempt to strengthen institutional legitimacy through the launch of certification (Orsato et al. 2013).

During the same year, the annual Roundtable conference was characterized by substantial debate. Following the adoption of the European Union's Renewable Energy Directive in 2009, NGOs and downstream firms, such as consumer manufacturers or retailers, proposed including similar greenhouse gas (GHG) emission criteria in the RSPO, whereas another group of RSPO members threatened to walk out of the General Assembly due to these newly proposed criteria (Adnan 2009). At the same time, the number of voices that had an influence within the RSPO was still limited. Farmers and local communities found it difficult to be heard because they used the forum to complain and accuse plantation companies, and because they relied on specific cases with very long histories (Cheyns 2014). A Dutch industry representative explained that by raising land right issues during the plenary debate, and how they did so, local communities caused a "negative energy" and proposed converting their participation to indirect representation via an NGO on the Executive Board (Cheyns 2014).

Assessing this second phase in terms of systemic change, the influence of the RSPO on the breadth and depth of 
systemic change become more evident yet still limited. By creating a certification system, the RSPO was able to establish connection between multiple spheres: an institution providing certification as a "signal" on sustainability, new technology to verify and support certification, organizations such as manufacturers and farmers valuing this certification and, last but not the least, consumer awareness on palm oil and its certification raised. Moreover, the Roundtable was able to establish connection, most notably between agricultural production, deforestation and the issue of poverty, thus involving multiple economic subsectors other than pal oil itself. Furthermore, NGOs, mostly Southern ones, were empowered by being part of the MSP and having access to diverse contacts, knowledge resources and working groups. Nevertheless, significant power shifts within the palm oil value chain still did not occur in this phase.

\section{Phase 3 (2010-2013): Increased Encounter of Wickedness and Increased Value Conflict}

While in the previous period the wickedness of the problem already became apparent, the dynamic complexity of palm oil production was increasingly embraced by the RSPO from 2010 onwards. A growing number of issues linked to palm oil production arose and were discussed in the RSPO, both raised by RSPO members and by external organizations, especially NGOs.

The issue of GHG emissions resulting from growing palm oil on peat lands became one of the focal points of discussion. The RSPO reacted with the establishment of a variety of working groups. Two science-based working groups on GHG were active in RSPO from 2009 to 2011 to identify ways to achieve reductions of GHG emissions. One of the outputs was the development of PalmGHG, a GHG calculator using life cycle assessment to quantify major sources of emissions and sequestration for individual palm oil mills and their supply base (Bessou et al. 2014). Debates took place mostly during the annual Roundtable meetings and General Assemblies whereby a clear preference for data from NGOs and companies becomes evident. Although the knowledge input is fairly diverse, the use of these different inputs is rather restricted; input from academia, farmers' associations and communities is not considered when knowledge is processed (Offermans and Glasbergen 2015). Knowledge supply is diverse when looking at the domains that are involved in producing knowledge, but also relatively homogeneous because of the input is dominated by NGOs (Offermans and Glasbergen 2015).

After 5 years of implementation, in 2012-2013, the P\&C were reviewed by the RSPO P\&C Review Taskforce and Steering Group in accordance with the RSPO P\&C Review Process. During the revision process of RSPO's P\&Cs, the conflict about GHG surfaced again. Value clashes prevented clear, stringent rules on GHG emissions or a moratorium on use of peat lands, leading to a situation of impasse. Articles in the Malaysian newspaper "The Star" highlighted Malaysian oil palm growers' objection to the fact that the revised RSPO P\&C seek to minimize GHG emissions from new plantings (Wong 2013). In a response, the RSPO urged their members to vote in favor of the revised $\mathrm{P} \& \mathrm{C}$ during an extraordinary general assembly (RSPO 2013) and in April 2013 the revised $P \& C$ were indeed approved. In the revised $\mathrm{P} \& \mathrm{C}$ "growers and millers have committed to an implementation period that begins with initially reporting to the RSPO, and after December 31, 2016, the commitment will transmit to public reporting." Even though this is a rather weak reporting criterion, it is still highly contentious. One of the arguments put forward by the opponents of GHG criteria to be included in the standard is that GHG emissions are mostly relevant in the context of biofuel usage but not in palm oil production.

Another source of contestation was the Dispute Settlement Facility which was introduced during the previous period. Mechanisms that were put in place, such as this Facility and third-party auditing, do not fully work in practice (i.e., in terms of monitoring and enforcement) and in turn led to new, exacerbated value conflicts. By disqualifying forms of proof that are drawn from a familiar engagement, the RSPO and its certification system reinforces existing power relations between local communities and companies, because the latter are able to provide formal proofs, while the former are not (Silva-Casteñada 2012). Local communities and NGOs have therefore challenged the majority of RSPO certificates, because they fail to recognize the existence of conflicts between certified companies and local communities (Silva-Casteñada 2012).

An assessment of this third phase in terms of systemic change reveals that breadth as well as depth of change remains limited. A few NGOs still remain major providers as knowledge input for companies managing the palm oil value chain, while the role of farmers' associations, communities and academia in informing and influencing the major business players remains limited. The example of how GHG are assessed and reported also illustrates that the industry has the strongest power of influencing decisions over key strategic issues. All in all, despite the mechanisms put in place to settle disputes between different stakeholders, the RSPO and its certification system seem not able to significantly shift power structures in and around the palm oil industry. 
Table 3 Harnessing dynamic complexity in governance processes: RSPO illustration

\begin{tabular}{|c|c|c|c|}
\hline \multirow[t]{2}{*}{ Dynamic complexity } & \multicolumn{3}{|c|}{ Key governance processes in the Roundtable on Sustainable Palm Oil } \\
\hline & Deliberation & Decision-making & Enforcement \\
\hline $\begin{array}{l}\text { Key question and summary of } \\
\text { evidence }\end{array}$ & $\begin{array}{l}\text { How does the MSP identify and } \\
\text { discuss emerging and re-emerg- } \\
\text { ing issues? } \\
\text { Issues emerged from sources (e.g., } \\
\text { actors, events) both inside and } \\
\text { outside the partnership. Issues } \\
\text { were discussed through formal } \\
\text { mechanisms, which also changed } \\
\text { over time. Yet, informal mecha- } \\
\text { nisms often do not facilitate } \\
\text { issue raising by resource-scarce } \\
\text { groups }\end{array}$ & $\begin{array}{l}\text { How does the MSP take decisions } \\
\text { on emerging issues? } \\
\text { Adopted criteria are revised over } \\
\text { time. New rules and reporting } \\
\text { criteria incorporate requests of } \\
\text { stakeholders external to the part- } \\
\text { nership. Decisions are de facto } \\
\text { postponed on highly contentious } \\
\text { issues. Limited participation in } \\
\text { deliberation also limits decision- } \\
\text { making }\end{array}$ & $\begin{array}{l}\text { How does the MSP implement } \\
\text { and monitor decisions made on } \\
\text { emerging issues? } \\
\text { Enforcement of decisions on } \\
\text { emerging issues limited by } \\
\text { the availability of resources. } \\
\text { Assessment tools developed only } \\
\text { at pilot level, thus with limited } \\
\text { outreach. Limited participation } \\
\text { in deliberation and decision- } \\
\text { making also limits enforcement } \\
\text { of decisions }\end{array}$ \\
\hline $\begin{array}{l}\text { Re-interpretation of the empirical } \\
\text { literature }\end{array}$ & $\begin{array}{l}\text { - Based on Oxfam Novib's criti- } \\
\text { cisms for insufficient representa- } \\
\text { tiveness in, the setting of the dis- } \\
\text { cussion on poverty changed over } \\
\text { time, a smallholder taskforce } \\
\text { (Oosterveer et al. 2014; Offer- } \\
\text { mans and Glasbergen 2015); } \\
\text { - Based on Greenpeace's Cooking } \\
\text { the Climate report (2013), two } \\
\text { Greenhouse Gas (GHG) emis- } \\
\text { sions working groups formed to } \\
\text { identify ways to achieve GHG } \\
\text { reductions (2009-2011) after that } \\
\text { (Bessou et al. 2014) } \\
\text { - Both biodiversity and cultural/ } \\
\text { spiritual values attached to a } \\
\text { specific area were incorporated } \\
\text { in the High Conservation Value } \\
\text { principle (Brandi et al. 2015) } \\
\text { - Distance, cost, language and } \\
\text { culture of RSPO meetings alien- } \\
\text { ate local stakeholders from the } \\
\text { RSPO meetings culture, thus } \\
\text { limiting their active participation } \\
\text { to discussions (Cheyns 2014; } \\
\text { Johnson 2014; Marin-Burgos } \\
\text { et al. 2015; Offermans and Glas- } \\
\text { bergen 2015) }\end{array}$ & $\begin{array}{l}\text { - NGOs and downstream firms } \\
\text { (e.g., manufacturers or retailers) } \\
\text { proposed and succeeded to } \\
\text { include GHG emission criteria } \\
\text { and targets in P\&C (Adnan } \\
\text { 2009) } \\
\text { - Due to Oxfam advocacy, RSPO } \\
\text { was forced to adjust social } \\
\text { criteria in P\&C to better specify } \\
\text { and link them to international } \\
\text { practices, and international norm } \\
\text { of Free, Prior, and Informed } \\
\text { Consent (2007) } \\
\text { - Through the creation of the a } \\
\text { smallholder farmer taskforce } \\
\text { (2005), RSPO created a system } \\
\text { of group certification for indi- } \\
\text { vidual smallholders to share the } \\
\text { costs of certification and be cer- } \\
\text { tified under a single certificate } \\
\text { - Smallholders and local com- } \\
\text { munities struggle to bring their } \\
\text { voice to the decision-making } \\
\text { table (Cheyns 2014; Johnson } \\
\text { 2014; Marin-Burgos et al. 2015; } \\
\text { Offermans and Glasbergen } \\
\text { 2015) } \\
\text { - Decisions on issues that are not } \\
\text { in the agenda of resource-rich } \\
\text { stakeholders, such as the orangu- } \\
\text { tan issue, are de facto postponed } \\
\text { (Ruysschaerts and Salles } 2014 \text { ) }\end{array}$ & $\begin{array}{l}\text { - The decisions taken on the } \\
\text { biodiversity loss (e.g., orangu- } \\
\text { tan issue) are weekly enforced: } \\
\text { financial compensation for oran- } \\
\text { gutan preservation is too small, } \\
\text { non-integration within the socio- } \\
\text { politico-legal Indonesian context } \\
\text { and lacking effective external } \\
\text { control system (Ruysschaerts } \\
\text { and Salles 2014) } \\
\text { - The monitoring of GHG emis- } \\
\text { sion computations are limited } \\
\text { to pilot field tests (Bessou et al. } \\
\text { 2014) } \\
\text { - In Colombia, RSPO field trips } \\
\text { show only the "brighter side" } \\
\text { of the palm oil industry, not } \\
\text { influenced by military and politi- } \\
\text { cal influences within the country } \\
\text { (Johnson 2014; Marin-Burgos } \\
\text { et al. 2015) } \\
\text { - Connected to limited participa- } \\
\text { tion in deliberation and decision- } \\
\text { making, smallholders and local } \\
\text { communities struggle to achieve } \\
\text { enforcement on the issue that } \\
\text { they raise (e.g., land conflict and } \\
\text { poverty) (Cheyns } 2014 ; \text { Johnson } \\
\text { 2014; Marin-Burgos et al. 2015; } \\
\text { Offermans and Glasbergen } 2015 \text { ) }\end{array}$ \\
\hline
\end{tabular}

\section{Harnessing Wicked Problems in the RSPO: An Empirical Illustration}

As becomes apparent from this historical overview, problems surrounding palm oil production involve an entangled bundle of issues that change over time and generate conflict and uncertainty as multiple stakeholders intervene and interact. Although entangled with each other in feedback loops-for example, knowledge uncertainty has often hampered stakeholders' awareness that problems were changing over time; or stakeholders raising new issues or taking different scientific approaches exacerbated value conflictthese dimensions of wickedness became more evident and distinguishable over time. This section illustrates how the RSPO responded to the dimensions of wickedness by adapting its organization over time. Tables 3,4 and 5 give a concise overview based on the conducted systematic literature review. 
Table 4 Harnessing value conflict in governance processes: RSPO illustration

\begin{tabular}{|c|c|c|c|}
\hline \multirow[t]{2}{*}{ Value conflict } & \multicolumn{3}{|c|}{ Key governance processes in the Roundtable on Sustainable Palm Oil } \\
\hline & Deliberation & Decision-Making & Enforcement \\
\hline $\begin{array}{l}\text { Key ques- } \\
\text { tion and } \\
\text { summary of } \\
\text { evidence }\end{array}$ & $\begin{array}{l}\text { How does the MSP take on and discuss } \\
\text { different and potentially conflicting } \\
\text { values underlying the issues at hand? } \\
\text { Formally, all stakeholders to the table for } \\
\text { discussion. Yet, conflicting views often } \\
\text { turn into some stakeholder leaving or } \\
\text { not joining the discussion table }\end{array}$ & $\begin{array}{l}\text { How does the MSP take decisions that } \\
\text { synthesize and mediate conflicting } \\
\text { values? } \\
\text { Majority voting does not allow a } \\
\text { synthesis between conflicting values. } \\
\text { Controversial decisions sometimes led } \\
\text { to exacerbation of contentious issues } \\
\text { within the RSPO. The most controver- } \\
\text { sial issues were sometimes left out of } \\
\text { the decision-making process }\end{array}$ & $\begin{array}{l}\text { How does the MSP deal with conflicting } \\
\text { values in the implementation and moni- } \\
\text { toring of decisions? } \\
\text { Monitoring and enforcement of decided } \\
\text { standards and dispute resolution among } \\
\text { conflicting stakeholders rarely takes } \\
\text { place because of resource scarcity and } \\
\text { even collusion issues }\end{array}$ \\
\hline $\begin{array}{l}\text { Re-interpre- } \\
\text { tation of the } \\
\text { empirical } \\
\text { literature }\end{array}$ & $\begin{array}{l}\text { - Formally, all stakeholders can par- } \\
\text { ticipate to debates online and general } \\
\text { assembly (Bessou et al. 2014; Marin- } \\
\text { Burgos et al. 2015; Offermans and } \\
\text { Glasbergen 2015) } \\
\text { - Because of conflicts between final con- } \\
\text { sumers and food manufacturers versus } \\
\text { large producers on the GHG emissions } \\
\text { issue, the Indonesian producer associa- } \\
\text { tion left the RSPO (Adnan 2009) } \\
\text { - In Colombia, Acciòn Ecologica } \\
\text { outspokenly decided not to participate } \\
\text { to discussions, and RSPO decided } \\
\text { not to further investigate why Acciòn } \\
\text { Ecologica decided not to participate or } \\
\text { incorporate their view into the RSPO } \\
\text { (Johnson 2014) } \\
\text { - Despite conflicts between Malay- } \\
\text { sian and Indonesian companies and } \\
\text { smallholders on the linkage between } \\
\text { palm oil and poverty, smallholders } \\
\text { do not have direct representation on } \\
\text { the Executive Board and on the P\&C } \\
\text { working group (Marin-Burgos et al. } \\
\text { 2015; Offermans and Glasbergen 2015) }\end{array}$ & $\begin{array}{l}\text { - Decision-making on smallholders' } \\
\text { participation to certification schemes } \\
\text { focused only on how they could } \\
\text { "conform to the RSPO standard" rather } \\
\text { than on the substance of the standard } \\
\text { itself: this prevented smallholders } \\
\text { from integrating their own visions of } \\
\text { sustainability into the standard (Cheyns } \\
\text { 2014). Farmers' attempts to influence } \\
\text { the content of the standard have gener- } \\
\text { ally been rejected (Cheyns 2014) } \\
\text { - Vote is based on a majority system } \\
\text { rather than seeking a synthesis among } \\
\text { different positions (Offermans and } \\
\text { Glasbergen } 2015 \text { ) } \\
\text { - In the revision of GHG report- } \\
\text { ing criterion in P\&C, value conflict } \\
\text { among stakeholders mounted on if } \\
\text { and how GHG emissions needed to be } \\
\text { considered in both food and biofuel } \\
\text { industries) (Schouten and Glasbergen } \\
\text { 2012) } \\
\text { - A Dispute Settlement Facility was } \\
\text { created as a mediation tool to resolve } \\
\text { disputes between local communities } \\
\text { and palm oil produces } \\
\text { - An Advisory Group was established to } \\
\text { help set it up and monitor any arising } \\
\text { cases }\end{array}$ & $\begin{array}{l}\text { - Enforcement of decisions on standards } \\
\text { is based on availability of resources } \\
\text { (e.g., funding, training, etc.) to support } \\
\text { resource-scarce stakeholders, but these } \\
\text { are sometimes not available (Oosterveer } \\
\text { et al. 2014; Brandi et al. 2015) } \\
\text { - Land conflicts seem to only be solved } \\
\text { if powerful players (e.g., interna- } \\
\text { tional NGOs) help rural communities } \\
\text { strengthen their bargaining position vis- } \\
\text { à-vis companies (Köhne 2014). Yet, out } \\
\text { of } 600 \text { palm oil related land conflicts in } \\
\text { Indonesia, only few affected communi- } \\
\text { ties were able to resort to the support of } \\
\text { external actors (Köhne 2014) } \\
\text { - Companies used the RSPO pre-certifi- } \\
\text { cate assessment as a legitimacy proof in } \\
\text { land conflicts with communities (Köhne } \\
\text { 2014) } \\
\text { - Report "Who watches the watchman?" } \\
\text { (EIA 2015) found that auditing firms } \\
\text { sometimes collude with companies to } \\
\text { hide standard violations (e.g., labor } \\
\text { abuses, land conflicts with local com- } \\
\text { munities). There were } 52 \text { complaints } \\
\text { of certification violations in the RSPO } \\
\text { system (EIA 2015) }\end{array}$ \\
\hline
\end{tabular}

\section{Harnessing Wickedness in Deliberation Processes}

Since its establishment, which took place as a response to an emerging issue, the RSPO has progressively adapted its organization to take into consideration new issues over time, such as deforestation, smallholders' poverty and violation of human rights, biodiversity loss, land conflicts and GHG emissions. These issues emerged from sources (e.g., actors, events) both inside and outside the partnership. As a response, issues were discussed through ad hoc formal mechanisms, such as working groups, which also evolved over time based on stakeholders' demands. Yet, more intangible issues around differences in culture, relationships and socioeconomic backgrounds have often hampered local stakeholders from raising an issue (harnessing dynamic complexity through deliberation, Table 3). For example, GHG emissions first emerged on the agenda of the RSPO in 2007 when Greenpeace published its report "Cooking the Climate," but it took two more years and the adoption of the European Union's Renewable Energy Directive in 2009, until environmental NGOs and downstream firms, such as consumer goods manufacturers and retailers, jointly advocated for the inclusion of GHG criteria and targets in the revised P\&C of the RSPO.

Reacting to different emerging issues over time, the RSPO provided and adapted its structure to take on and discuss the related conflicting values among stakeholders. While all stakeholders had formal access to the discussion in the RSPO, some actors decided to stay absent from the discussions or even leave the RSPO as a sign of protest, 
Table 5 Harnessing knowledge uncertainty in governance processes: RSPO illustration

\begin{tabular}{|c|c|c|c|}
\hline \multirow[t]{2}{*}{ Knowledge uncertainty } & \multicolumn{3}{|c|}{ Key governance processes in the Roundtable on Sustainable Palm Oil } \\
\hline & Deliberation & Decision-Making & Enforcement \\
\hline $\begin{array}{l}\text { Key question and summary of } \\
\text { evidence }\end{array}$ & $\begin{array}{l}\text { How does the MSP consult a } \\
\text { plurality of knowledge sources } \\
\text { and has meaningful discussions } \\
\text { under the condition of uncer- } \\
\text { tainty? } \\
\text { Scientific knowledge from a lim- } \\
\text { ited group of stakeholders was } \\
\text { sought to develop assessment } \\
\text { tools. Limited participation and } \\
\text { influence of other sources of } \\
\text { knowledge that are not consid- } \\
\text { ered as scientific }\end{array}$ & $\begin{array}{l}\text { How does the MSP acknowledge } \\
\text { knowledge uncertainty and } \\
\text { integrate a plurality of knowl- } \\
\text { edge perspectives when taking } \\
\text { decisions? } \\
\text { Despite a consideration to dif- } \\
\text { ferent knowledge sources, only } \\
\text { knowledge from few interna- } \\
\text { tional NGOs and companies } \\
\text { has been processed to develop } \\
\text { assessment tools for stand- } \\
\text { ards. The approach of using } \\
\text { knowledge is mostly based on }\end{array}$ & $\begin{array}{l}\text { How does the MSP use results from } \\
\text { a plurality of knowledge sources } \\
\text { when implementing and monitor- } \\
\text { ing decisions? } \\
\text { Very limited heterogeneity of } \\
\text { methods and perspectives used } \\
\text { to monitor and enforce decisions } \\
\text { on data collection and analysis } \\
\text { on multiple issues tackled by the } \\
\text { RSPO. On GHG emissions, data } \\
\text { collection and analysis is based } \\
\text { on self-assessment and, so far, on } \\
\text { a limited sample }\end{array}$ \\
\hline
\end{tabular}

Re-interpretation of the empirical Environmental consultancy firm literature

ProForest to conduct technical studies for further insights. These studies formed the basis for the initial discussions among all stakeholders and seemingly addressed the knowledge uncertainty about palm oil. These ProForest technical studies helped to narrow down and clearly demarcate the problem at a very early stage (Nikoloyuk et al. 2010)

- Science-based working groups on GHG emission issues developed PalmGHG, a calculator using life cycle assessment to quantify major sources of emissions and sequestration for individual palm oil mills and their supply base (Bessou et al. 2014)

- Unilever and WWF able to hold key positions during the multistakeholder processes and steer the discussions based on pragmatism and technical rationality (Schouten and Glasbergen 2012; Ponte \& Cheyns 2013), while local stakeholders found difficult to let their knowledge be heard given the structure of RSPO events (Cheyns 2014; Johnson 2014) choosing knowledge rather than integrating it

- At the stage of choosing and processing knowledge for informing RSPO decisions, only data from companies and NGO are processed and interpreted. Instead, knowledge from academia, farmers' associations and local communities has not been considered on various issues (e.g., smallholder poverty, GHG emissions) between 2009 and 2012 (Bessou et al. 2014; Offermans and Glasbergen 2015)

- On various issues, the RSPO took an approach of choosing rather than integrating different knowledge approaches from stakeholders between 2007 and 2013 (Marin-Burgos et al. 2015; Oosterveer et al. 2014; Offermans and Glasbergen 2015)

- While informally RSPO stakeholders recognize that no knowledge approach guarantees certain outcomes on the issues tackled in the RSPO, RSPO criteria do not explicitly consider uncertainty in the assessment tools developed so far (Bessou et al. 2014; Offermans and Glasbergen 2015)
- Data collection and analysis on GHG emissions is implemented exclusively by one stakeholder group (companies), which are asked to self-assess their performance (Bessou et al. 2014).

Moreover, pilot tests suffered of limited data availability at company level in 2012 and 2013 (Bessou et al. 2014)

- The GHG calculator was developed from a knowledge approach chosen by environmental consultancy firms and energy companies (Bessou et al. 2014), so little input from other stakeholders was used in the assessment

- Land titling was needed to receive RSPO certification, but this enforcement system was contested because it implies an acceptance of market-based mechanisms for a monetary evaluation of land (Johnson 2014). Thus, the perspective of stakeholders providing a sociocultural value to the land was ignored at a monitoring level (Johnson 2014) thus pushing the conflict outside the RSPO (harnessing value conflict through deliberation, Table 4). Furthermore, the RSPO has overall consulted a heterogeneous, yet limited group of stakeholders to better understand the debated issues and develop appropriate assessment tools. Participation and influence was limited to those sources that were considered as technical and objective (harnessing knowledge uncertainty through deliberation, Table 5). For example, given the knowledge uncertainty and value conflicts between the proponent of GHG emissions targets and palm oil producers, the RSPO commissioned a first working group (WG1) in 2008 to review all stages of the palm oil supply chain and create support for voluntary actions to reduce emissions. As no consensus for 
decision-making could be reached, another working group (WG2) was established in 2009, comprising both members of the Executive Board as well as 20 non-RSPO members, with representation from each of the RSPO's constituting groups. WG2 was tasked with developing a framework for verifiable reductions in GHG emissions. To reduce further value conflict, processes of deliberation within WG2 were focused on getting a better scientific understanding of the problem and developing technical measurement tools (Bessou et al. 2014). This was supposed to lay the foundation for a legitimate decision-making process surrounding the revised $\mathrm{P} \& \mathrm{C}$.

\section{Harnessing Wickedness in Decision-Making Processes}

In the face of several issues which have emerged over time, the RSPO has been hesitant and slow in changing decisionmaking processes accordingly. The $\mathrm{P} \& \mathrm{C}$ have been revised over time to incorporate requests of some stakeholders within the RSPO. Yet, decisions on highly contentious issues (e.g., biodiversity loss) have been postponed over time, and limited informal access to RSPO meetings also hampered representativeness of stakeholders in decision-making on new issues (harnessing dynamic complexity through decision-making, Table 3). Furthermore, the majority voting system in decision-making has often prevented a synthesis between conflicting values. Controversial decisions sometimes led to exacerbating contentious issues in the RSPO (harnessing value conflict through decision-making, Table 4). For example, at a decision-making stage, GHG emissions turned into one of the most polarized issues among RSPO members with a pronounced split between "final consumers" and "large producers" (Ruysschaerts and Salles 2014; Moreno-Peñaranda et al. 2015). Particularly Indonesian stakeholders were opposed to introducing criteria and targets for GHG emissions (Khor 2011). In 2011, GAPKI - the Indonesian Palm Oil Association- even withdrew from the RSPO, while simultaneously the Indonesian Government announced to develop its own standard for certification (the ISPO). The ISPO was explicitly designed as a competitor standard with lower environmental criteria than the RSPO (Schouten and Bitzer 2015). Also after GAPKI's exit, value conflicts prevailed and prevented the development of stringent rules on GHG emissions or a moratorium on the use of peat lands for palm oil production.

Along with this response to value conflicts, the decisionmaking process in the RSPO showed only limited integration of different knowledge perspectives. Despite considering different knowledge sources, only knowledge from few international NGOs and companies has been processed to develop assessment tools for standards across different issues. Therefore, the approach of using knowledge in taking decisions has mostly been based on choosing one knowledge perspective rather than integrating them (harnessing knowledge uncertainty through decision-making, Table 5). For example, on the issue of reducing GHG emissions, the revised P\&C in 2013 contained new rules on reducing emissions from new plantings (criterion 7.8) and reporting on the reductions from 2017 onward (voted in by 213 with only six votes against the decision). Companies are also required to use PalmGHG, a tool to quantify major sources of emissions and sequestration for individual palm oil mills and their supply base developed by WG2, to demonstrate compliance with the P\&C. Yet, many NGOs and activists were disappointed that these rules do not go far enough on GHG emissions (Nesadurai 2013). Palm oil producers, on the other hand, perceived the new rules as yet another unfair burden placed on their shoulders (Adnan 2013).

\section{Harnessing Wickedness in Enforcement Processes}

Problems in enforcement and implementation of jointly agreed interventions and standards have raised new issues in the RSPO and exacerbated value conflict. First of all, the enforcement of decisions on emerging issues was subject to stakeholders having the needed resources to make use of the decisions taken-which oftentimes turned out to be a significant hurdle (Moreno-Peñaranda et al. 2015). For example, local communities had limited resources to file complaints on the agreed procedures related to land conflict issues with palm oil companies, or smallholders found the financial compensation for orangutan preservation too small for changing their practices on this emerging issue (harnessing dynamic complexity through enforcement, Table 3 ). Furthermore, monitoring standard compliance and implementing dispute resolution mechanisms among conflicting stakeholders have been hampered by resource scarcity and even collusion issues (harnessing value conflict through enforcement, Table 4). This has contributed to widespread non-compliance with the RSPO standard among members (Laurance et al. 2010). Finally, impact assessment tools have been developed and used with very limited consideration of the variety of knowledge and perspectives brought by different stakeholder issues (harnessing knowledge uncertainty through enforcement, Table 5). For example, during the preparations for the 2013 revision of the P\&C, a pilot study was carried out in 2011 with just nine RSPO companies to check the applicability of PalmGHG as a management tool and its ease of implementation. While this allowed for some modifications to the tool before decision-making took place, it is also reported that there are still problems with regard to site-specific attunement of the tool (Bessou et al. 2014). Since the adoption of the revised $P \& C$ in 2013, the Emission Reduction Working Group (ERWG) was tasked with reviewing and fine-tuning the tools, emission factors 
and methodologies during the so-called implementation period, until criterion 7.8 entered into force at the beginning of 2017.

\section{Discussion and Conclusion}

\section{Contributions to the Literature on Cross-Sector Partnerships and Systemic Change}

This conceptual paper brings a governance perspective to the debate on how MSPs deal with complex societal challenges and support processes of systemic change to adequately address them. The study builds on the notion that, given the complex nature of the challenges at hand, systemic change requires the use of less conventional approaches (Colquitt and George 2011; Ferraro et al. 2015) to instigate remarkable shifts in power structures (i.e., depth of systemic change), as well as supporting change across multiple societal spheres and subsectors (i.e., breadth of systemic change) (Waddell et al. 2015; Waddock et al. 2015). In this context, harnessing complexity is necessary to support systemic change in ways that address the nature of the problems (Cohen and Axelrod 2000). To further understand how MSPs can approach the nature of problems, this paper has introduced the notion of harnessing wicked problems and investigates whether and how MSPs harness wicked problems through a set of interrelated governance processes. By way of operationalization, the paper has proposed an analytical framework entailing a set of questions and elements that empirically reflect (i.e., operationalize) what harnessing wicked problems means in the context of MSPs.

The proposed framework articulates how MSPs harness wicked problems along their three key dimensions (i.e., dynamic complexity, value conflict and knowledge uncertainty) during the key governance processes (i.e., deliberation, decision-making and enforcement). These three dimensions come to the fore in all governance processes of MSPs, which contributes to previous studies on MSP governance (e.g., Roloff 2008; Seitanidi and Crane 2009; Schouten and Glasbergen 2012). As such, the framework contributes to the literature on cross-sector partnerships by explaining how forms of collaborative governance adapt to changes, conflicts and uncertainty in the external environment. Furthermore, it contributes to the literature on the governance of wicked problems, as it provides a parsimonious way of assessing and comparing how MSPs harness the problem dimensions that they seek to tackle. In advancing such a governance perspective to understand how MSPs deal with wicked problems over time, this analytical framework adds to existing explanations for partnerships' organizational change.
We wish to highlight two key contributions to this scholarly debate on the governance of cross-sector partnerships and systemic change. First, our paper contributes to problem-based research on MSPs by assessing changes in the organizational form of MSPs through the theoretical lens of wicked problems. Despite repeated calls for further insights on how MSPs address complex societal problems-specifically on the impact of MSPs (e.g., van Tulder et al. 2016) studies that actually bridge the gap between MSPs and the problems they seek to address are scarce. Such a problembased perspective is missing even in recent studies, which, similarly to our study, recommend for organizations to internally embrace the complexity in their external environment (Schneider et al. 2016). The very basis of problem-based approaches dictates that "if one wants to solve a problem, one must generally know what the problem is" (Kerlinger and Lee 2000, p. 24). Thus, taking a wicked problem perspective to the organization of MSPs resonates with the idea that these arrangements operate in complex systems which follow nonlinear patterns and which must be carefully understood before instigating action (Waddock et al. 2015). Moving wicked problems to the fore when analyzing collaborative governance enhances our understanding of the linkages between MSPs and field-level impacts toward systemic change (Colquitt and George 2011; Ferraro et al. 2015).

Second, we argue that the framework developed in this paper helps providing a partial explanation to changes in the organization of partnerships seeking to address societal problems (Selsky and Parker 2010), by linking such changes to attempts of harnessing different problem dimensions. For example, the RSPO engaged in new discussions, reconfigured its knowledge sources or involved new actors as a response to new issues that emerged over time (e.g., poverty, GHG emissions or biodiversity loss). Furthermore, the framework helps to explain why partnerships may be criticized by stakeholders outside their boundaries, and why they may terminate, lose momentum or experience their members leaving and/or joining competing institutions when they do not harness some dimensions of the problems (Hahn and Pinkse 2014; Schouten and Bitzer 2015). For example, given the struggles that the RSPO faced in harnessing value conflict and knowledge uncertainty, especially in its decision-making and enforcing processes, Indonesian palm oil producers and other local stakeholders left the RSPO and founded a rival certification scheme.

Having said this, the example of the RSPO shows that it is very challenging to identify any causal relationship between organizational changes in MSPs and the breadth or depth systemic (Waddell et al. 2015). Our analysis indicates a limited ability of the RSPO to trigger systemic change, at least not in the way that we interpret the concept. The idea of an MSP, such as the RSPO, is to use the power of market 
actors to create systemic change. At the same time, this is also constraining, as power structures do not change, thus limiting the depth of systemic change a priori. Furthermore, systemic change takes time and is unlikely to occur quickly as a result of top-down interventions. There might be nonlinear effects with time delays, indicating that specific triggers may only take effect and manifest in systemic change after a considerable period of time. This makes systemic change, both as a process and an outcome, difficult, if not impossible, to assess. Both empirically and conceptually, systemic change remains an elusive term worth to be further investigated for promoting a discussion about the direction and nature of change promoted in MSPs in relation to the nature of wicked problems.

\section{Alternative Explanations of Organizational Change in Cross-Sector Partnerships}

Rather than attributing changes in the organization of MSPs solely to the nature of wicked problems, we concur with Selsky and Parker (2010) who suggest alternative explanations on the basis of a combination of stakeholder influence and societal interest. As such, MSPs may implement changes to their organization more or less rapidly depending on the salience of the stakeholders (Mitchell et al. 1997; Bowen et al. 2010) who raise an issue, participate in a conflict, or propose a knowledge approach. According to Mitchell et al. (1997), stakeholders are salient to an organization (such as an MSP) when they have power to influence it, when their requests are perceived as legitimate and when their claims entail a sense of urgency. In the RSPO, for example, the partnership started adapting its governance form once stakeholders which were perceived as powerful and legitimate, such as European customers and Oxfam Novib, increased their pressure on the palm oil industry with regard to GHG emissions and smallholder poverty issues. By contrast, demands from Indonesian producers-who may have been considered as less powerful and legitimate - to distribute the costs of certification along the value chain did not lead to significant organizational changes. Research on other MSPs in the agro-food sector has similarly shown the important role of stakeholder salience in promoting organizational changes of MSPs (Dentoni and Peterson 2011).

A second alternative explanation of why MSPs engage in organizational change may relate to their attempt to create and maintain legitimacy in national or international contexts of insufficient public regulation (e.g., Schouten and Glasbergen 2011). Mena and Palazzo (2012), for instance, suggested that MSPs emerge and develop their organization depending on the institutional framework surrounding the problem, rather than based on the nature of the problem. When problems transcend national boundaries, the limitations of government regulation create a legitimacy void
(Scherer and Palazzo 2011) which may require private actors to develop new strategies to cope with multiple and contradictory stakeholders' pressures (Pache and Santos 2010; Scherer et al. 2013). This view is also reflected in the RSPO, as the partnership receives pressures to adapt their enforcement mechanisms (e.g., effective monitoring on certification, support to resource-scarce stakeholders in the dispute settlement) due to the voids left by public regulation in palm oil producing countries. Along with transcending national boundaries, problems are also to some extent embedded in pre-existing relationships and mechanisms which can also shape MSP governance processes (Levy and Newell 2002). For example, in the RSPO case, the rules of international trade set by the World Trade Organization (WTO) formally constrain enforcement processes.

To integrate these different streams of knowledge on how MSPs change or evolve in addressing complex problems, future studies may explore if and how the process of harnessing wicked problems relate to stakeholder salience and international and national regimes. In particular, do stakeholder salience and changes in national or international regimes influence how MSPs harness wicked problems? Institutional theory indeed suggests that actors deal with complexity in partnerships differently depending on their position relative to stakeholders (Scherer et al. 2013) and the role of public regulation (Scherer and Palazzo 2011). Yet, no study has specifically focused on how stakeholder salience and the institutional framework influence a MSP approach in dealing with knowledge uncertainty, value conflict and dynamic complexity. Vice versa, does the process of harnessing wicked problems in MSPs influence stakeholder salience and the broader national or international regimes? For example, can deliberation, decision-making and enforcement processes in MSPs significantly shift power balances, or change perceptions of urgency and legitimacy of a stakeholder requests? Can these processes in MSPs even contribute to influencing overarching institutional and policy frameworks? While this role of partnerships would have remarkable implications for determining the depth and breadth of systemic change (Waddell et al. 2015; Waddock et al. 2015), there is still limited empirical evidence to address these questions. To further investigate those, the case of the RSPO can provide a fertile ground for observation and analysis in the years to come.

\section{Implications for Practitioners in Multi-stakeholder Partnerships}

What guidance can our framework of harnessing wicked problems during the key governance processes of MSPs offer to practitioners? While our framework was initially developed to guide the operationalization of harnessing 
wicked problems (for empirical purposes), it can also be further expanded into a more prescriptive framework, especially when revisiting the three dimensions of wicked problems. This does not result in a list of universally applicable action points, but requires a context- and stakeholder-specific approach.

Taking this into account, first, our framework provides indications of how to operate under conditions of knowledge uncertainty in which not only causes and effects of the problem itself are unclear, but also the consequences of MSP action are difficult to predict. This entails that MSPs should:

- Take into account different types of knowledge sources in processes of deliberation, decision-making and enforcement;

- Adapt decisions and ways of enforcement in response to newly emerging knowledge; and

- Carefully monitor implementation and evaluate impacts of the decisions taken involving, to any possible extent, a multiplicity of knowledge sources.

Second, the framework highlights the importance of addressing and mitigating value conflicts among stakeholders on the issues at hand. When opposing stakeholders define the problem to the exclusion of other definitions, a lack of harnessing value conflicts and a resulting lack of synthesis can lead to fragmentation and reduced incentives for collaboration. Therefore, MSPs should:

- Facilitate authentic processes of deliberation among relevant stakeholders with possibly conflicting values with the objective of inclusion and synthesis;

- Put mechanisms for dispute settlement in place (regarding deliberation, decision-making and enforcement); and

- Acknowledge new value conflicts that might arise from decisions that are taken and ways of enforcing those decisions.

Third, harnessing wickedness indicates that MSPs should be prepared to continuously take into account newly emerging and re-emerging issues-and realize that what worked before for some issues of the wicked problem will not necessarily work for other issues. This implies that MSPs should:

- Continuously (re-)assess emerging and re-emerging issues raised inside and outside of the MSP;

- Continuously (re-)assess the spectrum of relevant stakeholders to include in deliberation processes, decisionmaking processes and processes regarding enforcement; and
- Flexibly amend the existing governance processes and structures based on the nature of (re-)emerging issues.

While the literature suggests that understanding and adapting to the nature of problems may support deeper and broader systemic change (Waddock et al. 2015), the nature itself of wicked problems suggests prudence in reaching universal prescriptions on how to tackle them. Instead, the choice of MSPs to harness problems involves a number of trade-offs and dilemmas in itself. On the one hand, process of harnessing wicked problems may help MSPs to anticipate the unintended consequences of their decisions and interventions. This view resonates with the established idea that not only collaborative partnerships, but all organizations need to develop structures to deal with environmental complexity (Tushman and Nadler 1978; Schneider et al. 2016). On the other hand, harnessing wicked problems may seem like a never-ending process, perhaps even a vicious cycle, in which raising new issues leads to the discovery of even more new issues and so forth. Therefore, the incentives for stakeholders to embark on these governance processes may not be apparent at first sight. However, this paper illustrates that it may be an inevitable process for MSPs aiming to address complex societal problems. Under this lens, the evolution of the RSPO clearly shows that denying wickedness does not succeed over time. Moreover, the different dimensions of "harnessing" facilitate a process toward a deeper understanding of the problem, which is an indispensable prerequisite for meaningful action toward these problems. Harnessing wicked problems is undeniably a challenging task and requires reflexivity (of own ways of harnessing), flexibility (to adapt current ways of harnessing) and responsiveness to (re-)emerging issues and conflicting values under conditions of uncertainty.

\section{Compliance with Ethical Standards}

Conflict of interest The authors declare that they have no conflict of interest.

Ethical Approval This article does not contain any studies with human participants or animals performed by any of the authors.

Open Access This article is distributed under the terms of the Creative Commons Attribution 4.0 International License (http://creativeco mmons.org/licenses/by/4.0/), which permits unrestricted use, distribution, and reproduction in any medium, provided you give appropriate credit to the original author(s) and the source, provide a link to the Creative Commons license, and indicate if changes were made. 


\section{Appendix: A brief overview of the wicked problem of palm oil production}

\begin{tabular}{|c|c|c|}
\hline $\begin{array}{l}\text { Sustainability issues } \\
\text { related to palm oil } \\
\text { production }\end{array}$ & Explanation & References \\
\hline Biodiversity loss & $\begin{array}{l}\text { Conversion of either } \\
\text { primary or second- } \\
\text { ary forests to oil } \\
\text { palm results in } \\
\text { significant biodi- } \\
\text { versity loss }\end{array}$ & $\begin{array}{l}\text { Koh and Wilcove } \\
\text { (2008) }\end{array}$ \\
\hline $\begin{array}{l}\text { Deforestation and } \\
\text { peat land conver- } \\
\text { sion }\end{array}$ & $\begin{array}{l}\text { Analysis of land- } \\
\text { cover data suggests } \\
\text { that during the } \\
\text { period 1990-2005, } \\
55-59 \% \text { of oil } \\
\text { palm expansion in } \\
\text { Malaysia, and at } \\
\text { least } 56 \% \text { of that in } \\
\text { Indonesia occurred } \\
\text { at the expense of } \\
\text { forests. Oil palm } \\
\text { expansion has also } \\
\text { resulted in the } \\
\text { conversion of peat } \\
\text { lands leading to } \\
\text { increased carbon } \\
\text { dioxide emissions, } \\
\text { annual fires, as } \\
\text { well as increased } \\
\text { subsidence and } \\
\text { flood risk }\end{array}$ & $\begin{array}{l}\text { FAO (2007), Afriyanti } \\
\text { et al. (2016) }\end{array}$ \\
\hline $\begin{array}{l}\text { GHG emissions and } \\
\text { bioenergy }\end{array}$ & $\begin{array}{l}\text { Land use change is } \\
\text { the most prominent } \\
\text { factor in overall } \\
\text { GHG emissions } \\
\text { from palm oil } \\
\text { production. Palm } \\
\text { oil energy chains } \\
\text { based on land that } \\
\text { was previously } \\
\text { natural rainforest or } \\
\text { peat land have such } \\
\text { large emissions that } \\
\text { they cannot meet } \\
\text { emission reduction } \\
\text { targets }\end{array}$ & Wicke et al. (2008) \\
\hline
\end{tabular}

Sustainability issues Explanation References related to palm oil production

\begin{tabular}{ll}
\hline Haze & Haze-a weather \\
phenomenon that & Padfield et al. (2016) \\
& leads to an atmos- \\
pheric visibility of & less than 10 km due \\
& to suspended solid \\
& or liquid particles, \\
& smoke and vapor in \\
& the atmosphere-in \\
& Southeast Asia is \\
& commonly caused \\
& by the burning of \\
& forest and peat \\
& soils to make way \\
& for agricultural \\
& development, \\
& predominantly \\
& associated with oil \\
& palm cultivation. \\
& In early 2014, the \\
& haze was intensi- \\
& fied by an unusu- \\
ally long dry spell & of weather. Major \\
societal disruption \\
resulted, including \\
closure of schools, \\
in an increase in \\
haze-related health \\
issues, disruption \\
of airline sched- \\
ules, etc. \\
A nine-month \\
investigation of the \\
industry revealed \\
widespread abuses \\
of basic human \\
rights. Among \\
an estimated 3.7 \\
million workers \\
in the industry \\
are thousands of \\
child laborers and \\
workers who face \\
dangerous and abu- \\
sive conditions \\
\end{tabular}


Sustainability issues Explanation References related to palm oil production

Land conflicts
Disagreements and uncertainty over land tenure are widespread and can be violent. Conflicts between communities and companies have resulted almost entirely from lack of transparency, the absence of Free, Prior and Informed Consent and unequal benefit sharing and have been exacerbated by the absence of clear land rights

Livelihoods of small- Around three million holder farmers (2010) smallholder farm-
Vermeulen and Goad (2006), Rist et al. ers are producing palm oil. Narratives of inclusion/exclusion might propose that the solution to rural poverty lies in incorporation into the oil palm economy. Yet McCarthy (2010) suggested that individuals who find themselves incorporated into oil palm under unfavorable conditions will not only remain poor but may even face deeper poverty. The likelihood of inclusion/exclusion or adverse incorporation depends on the terms under which smallholders engage with the oil palm industry

\section{References}

Adnan, H. (2009). Threat to market access looms. StarBiz, 12 November 2009.

Adnan, H. (2013). Oil palm growers fail to block adoption of new RSPO principles. The Star, 26 April 2013.

Afriyanti, D., Kroeze, C., \& Saad, A. (2016). Indonesia palm oil production without deforestation and peat conversion by 2050. Science of the Total Environment, 557, 562-570.

Andonova, L., Betsill, M., \& Bulkeley, H. (2009). Transnational climate governance. Global Environmental Politics, 9, 52-73.

Bäckstrand, K. (2006). Multi-stakeholder partnerships for sustainable development: rethinking legitimacy, accountability and effectiveness. Environmental Policy and Governance, 16(5), 290-306.

Bäckstrand, K., Khan, J., Kronsell, A., \& Lövbrand, E. (2010). The promise of new modes of environmental governance. In K. Bäckstrand, J. Khan, A. Kronsell, \& E. Lövbrand (Eds.), Environmental politics and deliberative democracy: Examining the promise of new modes of governance (pp. 3-27). Cheltenham: Edward Elgar.

Batie, S. S. (2008). Wicked problems and applied economics. American Journal of Agricultural Economics, 90(5), 1176-1191.

Baur, D., \& Arenas, D. (2014). The value of unregulated business-NGO interaction: A deliberative perspective. Business and Society, 53(2), 157-186.

Bessou, C., Chase, L. D., Henson, I. E., Abdul-Manan, A. F., Canals, L. M., Agus, F., et al. (2014). Pilot application of PalmGHG, the Roundtable on Sustainable Palm Oil greenhouse gas calculator for oil palm products. Journal of Cleaner Production, $73,136-145$.

Bitzer, V., \& Glasbergen, P. (2015). Business-NGO partnerships in global value chains: part of the solution or part of the problem of sustainable change? Current Opinion in Environmental Sustainability, 12, 35-40.

Bowen, F., Newenham-Kahindi, A., \& Herremans, I. (2010). When suits meet roots: The antecedents and consequences of community engagement strategy. Journal of Business Ethics, 95(2), 297-318.

Brandi, C., Cabani, T., Hosang, C., Schirmbeck, S., Westermann, L., \& Wiese, H. (2015). Sustainability Standards for Palm Oil: Challenges for smallholder certification under the RSPO. Journal of Environment \& Development, 24(3), 292-314.

Cheyns, E. (2014). Making "minority voices" heard in transnational roundtables: The role of local NGOs in reintroducing justice and attachments. Agriculture and Human Values, 31(3), 439-453.

Cheyns, E., \& Riisgaard, L. (2014). Introduction to the symposium: The exercise of power through multistakeholder initiatives for sustainable agriculture and its inclusion and exclusion outcomes. Agriculture and Human Values, 31(3), 409-423.

Cohen, M. D., \& Axelrod, R. (2000). Harnessing complexity: Organizational implications of a scientific frontier. New York: Simon and Schuster.

Colquitt, J. A., \& George, G. (2011). Publishing in AMJ—Part 1: Topic choice. Academy of Management Journal, 54(3), 432-435.

Conklin, J. (2006). Wicked problems and social complexity. Napa, USA: CogNexus Institute.

Crona, B., \& Parker, J. N. (2012). Learning in support of governance: Theories, methods, and a framework to assess how bridging organizations contribute to adaptive resource governance. Ecology and Society, 17(1), 32.

Dentoni, D., \& Bitzer, V. (2015). The role (s) of universities in dealing with global wicked problems through multi-stakeholder initiatives. Journal of Cleaner Production, 106, 68-78.

Dentoni, D., Hospes, O., \& Ross, B. (2012). Managing wicked problems in agribusiness: The role of multi-stakeholder engagements in value creation. International Food and Agribusiness Management Review, 15(B), 1-12.

Dentoni, D., \& Peterson, H. C. (2011). Multi-stakeholder sustainability alliances in agri-food chains: A framework for multi-disciplinary research. International Food and Agribusiness Management Review, 14(5), 83-108.

Dentoni, D., \& Ross, R. (2013). Towards a theory of managing wicked problems through multi-stakeholder engagements: Evidence 
from the agribusiness sector. International Food and Agribusiness Management Review, 16(A), 1-10.

Dietz, T., Ostrom, E., \& Stern, P. C. (2003). The struggle to govern the commons. Science, 302(5652), 1907-1912.

Dryzek, J. S., \& Stevenson, H. (2011). Global democracy and earth system governance. Ecological Economics, 70(11), 1865-1874.

Eckstein, H. (1975). Case studies and theory in political science. In F. Greenstein \& N. Polsby (Eds.), Handbook of political science (Vol. 7, pp. 79-138). Reading, MA: Addison-Wesley.

Environmental Investigation Agency (EIA). (2015). Who watches the watchmen? Auditors and the breakdown of oversight in the RSPO. Retrieved April 15, 2016 from https://eia-international. org.

FAO. (2007). FAOSTAT online statistical service. United Nations Food and Agriculture Organization (FAO), Rome. Retrieved August 15, 2017 from http://faostat.fao.org.

Ferraro, F., Etzion, D., \& Gehman, J. (2015). Tackling grand challenges pragmatically: Robust action revisited. Organization Studies, 36(3), 363-390.

Forsyth, T. (2010). Panacea or paradox? Cross-sector partnerships, climate change, and development. Wiley Interdisciplinary Reviews: Climate Change, 1(5), 683-696.

Fortin, E. (2013). Transnational multi-stakeholder sustainability standards and biofuels: Understanding standards processes. Journal of Peasant Studies, 40, 563-587.

Fransen, L. W., \& Kolk, A. (2007). Global rule-setting for business: A critical analysis of multi-stakeholder standards. Organization, 14(5), 667-684.

Geels, F. W., \& Schot, J. (2007). Typology of sociotechnical transition pathways. Research Policy, 36(3), 399-417.

George, G. (2014). Rethinking management scholarship. Academy of Management Journal, 57(1), 1-6.

Gray, B. (1989). Collaborating: Finding common ground for multiparty problems. San Francisco, CA: Jossey-Bass.

Gulbrandsen, L. H. (2004). Overlapping public and private governance: Can forest certification fill the gaps in the global forest regime? Global Environmental Politics, 4(2), 75-99.

Hahn, T., \& Pinkse, J. (2014). Private environmental governance through cross-sector partnerships: Tensions between competition and effectiveness. Organization \& Environment, 27(2), 140-160.

Hajer, M. (2003). Policy without polity? Policy analysis and the institutional void. Policy Sciences, 36(2), 175-195.

Hamilton, H. (2013). Sustainable food lab learning systems for inclusive business models worldwide. International Food and Agribusiness Management Review, 16(A), 33-38.

Hatanaka, M., \& Busch, L. (2008). Third-party certification in the global agrifood system: An objective or socially mediated governance mechanism? Sociologia Ruralis, 48(1), 73-91.

Head, B. W., \& Alford, J. (2013). Wicked problems: Implications for public policy and management. Administration \& Society, 47, 711-739. (on-line first).

Hospes, O., Kroeze, C., Oosterveer, P., Schouten, G., \& Slingerland, M. (2017). New generation of knowledge: Towards an inter- and transdisciplinary framework for sustainable pathways of palm oil production. NJAS-Wageningen Journal of Life Sciences, 80, $75-84$.

Hospes, O., van der Valk, O., \& Mheen-Sluijer, J. (2012). Parallel development of five partnerships to promote sustainable soy in Brazil: Solution or part of wicked problems. International Food and Agribusiness Management Review, 15(B), 39-62.

Ison, R., Collins, K. B., \& Wallies, P. J. (2015). Institutionalising social learning: Towards systemic and adaptive governance. Environmental Science \& Policy, 53(B), 105-117.

Jentoft, S., \& Chuenpagdee, R. (2009). Fisheries and coastal governance as a wicked problem. Marine Policy, 33(4), 553-560.
Johnson, A. (2014). Green governance or green grab? The roundtable on sustainable palm oil (RSPO) and its governing processes in Ecuador. LDPI working paper 54, Land Deal Politics Initiative (LDPI), ISS: The Hague.

Kerlinger, F. N., \& Lee, H. B. (2000). Foundations of behavioral research (4th ed.). Holt, NY: Harcourt College Publishers.

Khor, Y. L. (2011). The oil palm industry bows to NGO campaigns. Lipid Technology, 23(5), 102-104.

Klooster, D. (2010). Standardizing sustainable development? The Forest Stewardship Council's plantation policy review process as neoliberal environmental governance. Geoforum, 41, 117-129.

Koh, L. P., \& Wilcove, D. S. (2008). Is oil palm agriculture really destroying tropical biodiversity? Conservation letters, 1(2), 60-64.

Köhne, M. (2014). Multi-stakeholder initiative governance as assemblage: Roundtable on Sustainable Palm Oil as a political resource in land conflicts related to oil palm plantations. Agriculture and Human Values, 31, 469-480.

Kreuter, M. W., De Rosa, C., Howze, E. H., \& Baldwin, G. T. (2004). Understanding wicked problems: A key to advancing environmental health promotion. Health Education \& Behavior, 31(4), 441-454.

Laurance, W., Koh, L. P., Butler, R., Sodhi, N. S., Bradshaw, C. J. A., Neidel, J. D., et al. (2010). Improving the performance of the Roundtable on Sustainable Palm Oil for nature conservation. Conservation Biology, 24(2), 377-381.

Lazarus, R. J. (2008). Super wicked problems and climate change: Restraining the present to liberate the future. Cornell L. Rev., 94, 1153.

Levin, K., Cashore, B., Bernstein, S., \& Auld, G. (2012). Overcoming the tragedy of super wicked problems: Constraining our future selves to ameliorate global climate change. Policy Sciences, 45(2), 123-152.

Levy, D. L., \& Newell, P. J. (2002). Business strategy and international environmental governance: Toward a neo-Gramscian synthesis. Global Environmental Politics, 2(4), 84-101.

Loorbach, D. (2010). Transition management for sustainable development: A prescriptive, complexity-based governance framework. Governance: An International Journal of Policy, Administration, and Institutions, 23(1), 161-183.

Marin-Burgos, V., Clancy, J. S., \& Lovett, J. C. (2015). Contesting legitimacy of voluntary sustainability certification schemes: Valuation languages and power asymmetries in the Roundtable on Sustainable Palm Oil in Colombia. Ecological Economics, 117, 303-313.

McCarthy, J. F. (2010). Processes of inclusion and adverse incorporation: oil palm and agrarian change in Sumatra, Indonesia. Journal of Peasant Studies, 37, 821-850.

Mena, S., \& Palazzo, G. (2012). Input and output legitimacy of multistakeholder initiatives. Business Ethics Quarterly, 22(03), 527-556.

Mitchell, R. K., Agle, B. R., \& Wood, D. J. (1997). Toward a theory of stakeholder identification and salience: Defining the principle of who and what really counts. Academy of Management Review, 22(4), 853-886.

Moreno-Peñaranda, R., Gasparatos, A., Stromberg, P., Suwa, A., Hadi Pandyaswargo, A., \& Puppim de Oliveira, J. A. (2015). Sustainable production and consumption of palm oil in Indonesia: What can stakeholder perceptions offer to the debate? Sustainable Production and Consumption, 4, 16-35.

Nesadurai, H. E. (2013). Food security, the palm oil-land conflict nexus, and sustainability: A governance role for a private multistakeholder regime like the RSPO? The Pacific Review, 26(5), 505-529. 
Ney, S., \& Verweij, M. (2014). Exploring the contributions of cultural theory for improving public deliberation about complex policy problems. Policy Studies Journal, 42(4), 620-643.

Nikoloyuk, J., Burns, T. R., \& De Man, R. (2010). The promise and limitations of partnered governance: the case of sustainable palm oil. Corporate Governance: The international journal of business in society, 10(1), 59-72.

O'Rourke, D. (2006). Multi-stakeholder regulation: Privatizing or socializing global labor standards? World Development, 34(5), 899-918.

Offermans, A., \& Glasbergen, P. (2015). Boundary work in sustainability partnerships: An exploration of the Round Table on Sustainable Palm Oil. Environmental Science \& Policy, 50, 34-45.

Omont, H. (2004). Roundtable on sustainable palm oil (RSPO). Report of the second RSPO meeting in Jakarta, Indonesia, October 2004 (pp. 125-128).

Oosterveer, P., Adjei, B. E., Vellema, S., \& Slingerland, M. (2014). Global sustainability standards and food security: Exploring unintended effects of voluntary certification in palm oil. Global Food Security, 3, 220-226.

Orsato, R. J., Clegg, S. R., \& Falcão, H. (2013). The political ecology of palm oil production. Journal of Change Management, 13(4), 444-459.

Pache, A. C., \& Santos, F. (2010). When worlds collide: The internal dynamics of organizational responses to conflicting institutional demands. Academy of Management Review, 35(3), 455-476.

Padfield, R., Drew, S., Syayuti, K., Page, S., Evers, S., Campos-Arceiz, A., et al. (2016). Landscapes in transition: An analysis of sustainable policy initiatives and emerging corporate commitments in the palm oil industry. Landscape Research, 41(7), 744-756.

Pattberg, P. (2006). Private governance and the South: Lessons from global forest politics. Third World Quarterly, 27(4), 579-593.

Pesqueira, L., \& Glasbergen, P. (2013). Playing the politics of scale: Oxfam's intervention in the Roundtable on Sustainable Palm Oil. Geoforum, 45, 296-304.

Ponte, S., \& Cheyns, E. (2013). Voluntary standards, expert knowledge and the governance of sustainability networks. Global Networks, 13(4), 459-477.

Potts, J., Lynch, M., Wilkings, A., Huppé, G., Cunningham, M., \& Voora, V. (2014). The state of sustainability initiatives review 2014: Standards and the green economy. International Institute for Sustainable Development (IISD) and the International Institute for Environment and Development (IIED).

Rasche, A. (2012). Global policies and local practice: Loose and tight couplings in multi-stakeholder initiatives. Business Ethics Quarterly, 22(4), 679-708.

Rist, L., Feintrenie, L., \& Levang, P. (2010). The livelihood impacts of oil palm: Smallholders in Indonesia. Biodiversity and Conservation, 19(4), 1009-1024.

Rittel, H. W., \& Webber, M. M. (1973). Dilemmas in a general theory of planning. Policy Sciences, 4(2), 155-169.

Rivera-Santos, M., \& Rufin, C. (2011). Odd couples: Understanding the governance of firm-NGO alliances. Journal of Business Ethics, 94, 55-70.

Roberts, N. (2000). Wicked problems and network approaches to resolution. International Public Management Review, 1(1), 1-19.

Roloff, J. (2008). Learning from multi-stakeholder networks: Issuefocused stakeholder management. Journal of Business Ethics, $82,223-250$

RSPO. (2013). Statement from the RSPO Executive Board on the RSPO revised Principles and Criteria 2013. Retrieved November 4, 2013 from http://www.rspo.org/news_details.php?nid=151.

Rufin, C., \& Rivera-Santos, M. (2012). Between commonweal and competition: Understanding the governance of public-private partnerships. Journal of Management, 38, 1634-1654.
Ruysschaerts, D., \& Salles, D. (2014). Towards global voluntary standards: Questioning the effectiveness in attaining conservation goals: The case of the Roundtable on Sustainable Palm Oil (RSPO). Ecological Economics, 107, 438-446.

Sachs, S., Rühli, E., \& Meier, C. (2010). Stakeholder governance as a response to wicked issues. Journal of Business Ethics, 96(1), $57-64$.

Scherer, A. G., \& Palazzo, G. (2007). Toward a political conception of corporate responsibility: Business and society seen from a Habermasian perspective. Academy of Management Review, 32(4), 1096-1120.

Scherer, A. G., \& Palazzo, G. (2011). The new political role of business in a globalized world: A review of a new perspective on CSR and its implications for the firm, governance, and democracy. Journal of Management Studies, 48(4), 899-931.

Scherer, A. G., Palazzo, G., \& Seidl, D. (2013). Managing legitimacy in complex and heterogeneous environments: Sustainable development in a globalized world. Journal of Management Studies, 50(2), 259-284.

Schneider, A., Wickert, C., \& Marti, E. (2016). Reducing complexity by creating complexity: A systems theory perspective on how organizations respond to their environments. Journal of Management Studies, 54, 182-208.

Schouten, G., \& Bitzer, V. (2015). The emergence of Southern standards in agricultural value chains: A new trend in sustainability governance? Ecological Economics, 120, 175-184.

Schouten, G., \& Glasbergen, P. (2011). Creating legitimacy in global private governance: The case of the Roundtable on Sustainable Palm Oil. Ecological Economics, 70(11), 1891-1899.

Schouten, G., \& Glasbergen, P. (2012). Private multi-stakeholder governance in the agricultural market place: An analysis of legitimization processes of the Roundtables on Sustainable Palm Oil and responsible soy. International Food and Agribusiness Management Review, 15(B), 53-78.

Schouten, G., Leroy, P., \& Glasbergen, P. (2012). On the deliberative capacity of private multi-stakeholder governance: The roundtables on responsible soy and sustainable palm oil. Ecological Economics, 83, 42-50.

Seitanidi, M., \& Crane, A. (2009). Implementing CSR through partnerships: Understanding the selection, design and institutionalisation of nonprofit-business partnerships. Journal of Business Ethics, 85, 413-429.

Selsky, J. W., \& Parker, B. (2005). Cross-sector partnerships to address social issues: Challenges to theory and practice. Journal of Management, 31(6), 849-873.

Selsky, J., \& Parker, B. (2010). Platforms for cross-sector social partnerships: prospective sensemaking devices for social benefit. Journal of Business Ethics, 94, 21-37.

Senge, P. M., Lichtenstein, B. B., Kaeufer, K., Bradbury, H., \& Carroll, J. S. (2007). Collaborating for systemic change. MIT Sloan Management Review, 48(2), 44.

Silva-Castañeda, L. (2012). A forest of evidence: Third-party certification and multiple forms of proof-A case study of oil palm plantations in Indonesia. Agriculture and Human Values, 29, 361-370.

Skinner, B. (2013). Indonesia's palm oil industry rife with humanrights abuses: The hidden human toll of the palm oil boom, July 20, 2013, BloombergBusinessweek.

Termeer, C. J., Dewulf, A., Breeman, G., \& Stiller, S. J. (2015). Governance capabilities for dealing wisely with wicked problems. Administration \& Society. https://doi.org/10.1177/0095399712 469195.

Tushman, M. L., \& Nadler, D. A. (1978). Information processing as an integrating concept in organizational design. Academy of Management Review, 3, 613-624. 
van Tulder, R., Seitanidi, M. M., Crane, A., \& Brammer, S. (2016). Enhancing the impact of cross-sector partnerships. Journal of Business Ethics, 135(1), 1-17.

Vermeulen, S., \& Goad, N. (2006). Towards better practice in smallholder palm oil production. London: IIED.

Waddell, S., McLachlan, M., \& Dentoni, D. (2013). Learning and transformative networks to address wicked problems: A GOLDEN invitation. International Food and Agribusiness Management Review, 16(A), 23-32.

Waddell, S., Waddock, S., Cornell, S., Dentoni, D., McLachlan, M., \& Meszoely, G. (2015). Large systems change: An emerging field of transformation and transitions. Journal of Corporate Citizenship, 53, 5-30.

Waddock, S. (2013). The wicked problems of global sustainability need wicked (good) leaders and wicked (good) collaborative solutions. Journal of Management for Global Sustainability, 1, 91-111.

Waddock, S., Meszoely, G. M., Waddell, S., \& Dentoni, D. (2015). The complexity of wicked problems in large scale change. Journal of Organizational Change Management, 28(6), 993-1012.
Weber, E. P., \& Khademian, A. M. (2008). Wicked problems, knowledge challenges, and collaborative capacity builders in network settings. Public Administration Review, 68(2), 334-349.

Wicke, B., Dornburg, V., Junginger, M., \& Faaij, A. (2008). Different palm oil production systems for energy purposes and their greenhouse gas implications. Biomass and Bioenergy, 32(12), $1322-1337$.

Wijen, F. (2014). Compliance and achievement in sustainability standard adoption. Academy of Management Review, 39, 302-323.

Wong, J. (2013). GHG issues 'unnecessary burden on growers'. The Start Online.

Zeyen, A., Beckmann, M., \& Wolters, S. (2016). Actor and institutional dynamics in the development of multistakeholder initiatives. Journal of Business Ethics, 135(2), 341-360. 